\title{
Percepcija neranjivosti, upuštanje u rizična ponašanja i zadovoljstvo životom kod srednjoškolaca
}

\author{
Marija Milić \\ Odsjek za psihologiju, Filozofski fakultet, \\ Sveučilište Josipa Jurja Strossmayera u Osijeku \\ $\checkmark$ E-mail:mmilic@ffos.hr \\ Ružica-Marija Vlajčić \\ Valerija Križanić \\ Odsjek za psihologiju, Filozofski fakultet, \\ Sveučilište Josipa Jurja Strossmayera u Osijeku
}

\begin{abstract}
Sažetak
Osjećaj neranjivosti često se povezuje isključivo s rizičnim ponašanjem adolescenata. No, prema nekim razvojnim teorijama, ona je također i adaptivan odgovor na razvojne zadatke koji se javljaju u tom životnom razdoblju. Cilj ovoga rada bio je istražiti dva aspekta osjećaja neranjivosti (fizičke i psihološke) na uzorku srednjoškolaca. Preciznije, istražen je odnos fizičke i psihološke neranjivosti s upuštanjem u rizična ponašanja (konzumacijom cigareta) s jedne strane, te pokazateljima subjektivne dobrobiti (zadovoljstvo životom) s druge strane. U radu su analizirani podatci 297 sudionika dobi od 16 do 20 godina ( $\mathrm{M}=$ $17,33 \%$; SD = 0,834; 54,2 \% djevojaka). Istraživanjem je utvrđeno da su se mladići procjenjivali fizički i psihološki neranjivijim od djevojaka. Adolescenti koji puše, procjenjivali su svoju fizičku neranjivost većom od adolescenata koji su prestali pušiti, koji su samo probali pušiti i onih koji nikada nisu pušili. Dok fizička neranjivost nije povezana s procjenama na većini domena zadovoljstva životom, psihološka je pozitivno povezana sa svim domenama kao i s općim životnim zadovoljstvom. Utvrđeni rezultati također pokazuju da procjena psihološke neranjivosti u većoj mjeri pridonosi objašnjenju zadovoljstva životom od procjene fizičke neranjivosti, dok je fizička neranjivost značajan prediktor čestine pušenja adolescenata. Rezultati ovog istraživanja upućuju na značaj i važnost obiju domena neranjivosti u razdoblju adolescencije.
\end{abstract}

Ključne riječi: adolescenti, fizička i psihološka neranjivost, pušenje, zadovoljstvo životom

\section{Uvod}

Razdoblje adolescencije karakterizirano je intenzivnim promjenama u različitim aspektima funkcioniranja mladih osoba, a samim time nosi i niz novih izazova za adekvatnu prilagodbu. $\mathrm{S}$ druge strane, kod adolescenata se uočava izraženija sklonost rizičnom ponašanju nego kod drugih dobnih skupina (Steinberg, 2008). U tom životnom razdoblju zamjetan je drastičan porast rizičnih ponašanja koja ugrožavaju zdravlje (Arnett, 1992), uključujući korištenje alkohola, duhana, psihoaktivnih tvari, seksualne odnose bez zaštite (Zloković i Vrcelj, 2010). lako posljedice ovakvih ponašanja mogu biti raznovrsne i neke među njima adolescenti doživljavaju privlačnima (primjerice percipirana 
popularnost u vršnjačkoj skupini, osvajanje partnerice/partnera), društvo je zaokupljeno mogućim negativnim posljedicama takva ponašanja, ponajprije u vidu ugrožavanja života (zbog nesreća i neželjenih događaja povezanih s takvim oblicima ponašanja) i zdravlja mladih (Trimpop, 1994).

Ovaj se rad usmjerava na konzumaciju cigareta mladih, kao jednoga od oblika rizična ponašanja, čime pušači ugrožavaju vlastito zdravlje, ali i zdravlje drugih u izravnoj okolini. S jedne strane, pušenje je jedan od najpreventabilnijih rizičnih čimbenika u nastanku brojnih kroničnih bolesti, a s druge strane, pušenje cigareta označeno je jednim od vodećih uzroka obolijevanja u Republici Hrvatskoj, pri čemu je rizik osobito visok kod mladih koji započinju s pušenjem prije petnaeste godine života (prema Hrvatskom zavodu za javno zdravstvo [HZJZ], 2016). Praćenjem trendova upuštanja mladih u zdravstvena rizična ponašanja na temelju podataka međunarodnog istraživanja provedenog 2015., uočljivo je da je problematika konzumacije cigareta u Hrvatskoj zabrinjavajuće aktualna (HZJZ, 2016). Oko 62 \% učenika (prvih i drugih razreda) srednje škole izjavljuje da je pušilo jednom ili više puta u životu; oko 23 \% da je pušilo u posljednjih 30 dana; a isto toliki postotak ispitanih srednjoškolaca izjavljuje da puši svakodnevno. Usporede li se podatci s onima prikupljenima dvadeset godina ranije, u prosjeku se u zemljama uključenima u studiju smanjio udio srednjoškolaca koji svakodnevno puše, dok je u Hrvatskoj za 1 \% porastao (HZJZ, 2016).

S obzirom na moguće štetne posljedice takvih ponašanja za mlade osobe i njihovu okolinu, ali i nalaze istraživanja koji upozoravaju na potencijalne veze pušenja s kasnijim ozbiljnijim problemima u ponašanju (Ellickson, Tucker i Klein, 2001), čini se važnim produbiti razumijevanje tog fenomena (spremnosti na rizična ponašanja). Znanstveno utemeljene spoznaje o ključnim mehanizmima u podlozi upuštanja mladih u rizična ponašanja važna su karika u oblikovanju učinkovitijih društvenih intervencija i preventivnih programa. Svrha je ovoga rada pridonijeti skupu znanstvenih spoznaja o toj problematici.

Prema Kalebić Maglica i Martinac Dorčić (2015), razlozi upuštanja u rizična ponašanja dominantno su istraživani dvama pristupima: pristupom usmjerenim na osobine ličnosti te pristupom koji snažnije naglašava situacijske i šire socijalne kontekstualne čimbenike. Epidemiološki podatci upozoravaju da je 86,9 \% odraslih, koji su ikada pušili, počelo s tom navikom prije 18. godine (USDHHS, 2014). Stoga je važno utvrditi rizične čimbenike započinjanja pušenja prije tog razdoblja. Istraživanja upućuju na neke čimbenike uz koje postoji veća vjerojatnost započinjanja pušenja kod adolescenata, primjerice starija dob (O'Loughlin, Karp, Koulis, Paradis i DiFranza, 2009), uže socijalno okruženje u kojemu se puši (roditelji, braća/sestre, prijatelji; Gilman i sur., 2009), nisko samopoštovanje (Khosravi, Mohammadpoorasl, Naieni, Mahmoodi, Pouyan i AliMansournia, 2016), znatiželja, socijalni pritisak (Sarason, Mankowski, Peterson i Dinh, 1992), doživljavanja izrazito stresnih događaja (Bonilha, de Souza, Sicchieri, Achcar, Crippa i Baddini-Martinez, 2013), itd. U većem broju istraživanja utvrđeno je da adolescenti koji puše percipiraju više dobiti, a manje rizika vezanih za pušenje u odnosu na nepušače (Aryal, Petzold i Krettek, 2013; Halpern-Felsher, Biehl, Kropp i Rubinstein, 2004; Krosnick, Chang, Sherman, Chassin i Presson, 2006; Rodriguez, Romer i Audrain-McGovern, 2007; Romer i Jamieson, 2001; Song i sur., 2009). Kada se fokus usmjeri na specifičnu povećanu spremnost osoba adolescentske dobi na poduzimanje rizika, u literaturi se iz ovoga područja može uočiti široko zastupljeno gledište da tendencija adolescenata i njihova upuštanja u različite oblike rizičnih ponašanja proizlazi i dijelom iz njihova sve većeg osjećaja neranjivosti na opasnost, ozljede ili bilo kakvu štetu (Arnett, 1992; Hill, Dugan i Lapsley, 2012; Lapsley i Hill, 2010). Iz te bi se perspektive adolescentski 
osjećaj neranjivosti mogao smatrati psihosocijalnim rizičnim čimbenikom. Na nj bi u tom slučaju trebale biti usmjerene intervencije, želimo li što djelotvornije reducirati upuštanje adolescenata u zdravstveno rizična ponašanja (Trimpop, 1994). Međutim, nalazi dosadašnjih istraživanja o tom pitanju nisu konzistentni pa neki pronalaze angažman adolescenata u rizičnim ponašanjima čak i uz povećan osjećaj ranjivosti (npr. Cohn, Macfarlane, Yanez i Imai, 1995; Gerrard, Gibbons, Benthin i Hessling, 1996). Stoga bi se odluke o tome, treba li osjećaj ranjivosti uključivati u intervencije ili prevencijske programe te na koji način, morale temeljiti i na što jasnijem teorijskom razumijevanju osnovne funkcije osjećaja neranjivosti u normalnom razvoju adolescenata. U tumačenju osjećaja neranjivosti pretežno su korišteni kognitivni i razvojni pristup.

Kognitivni pristup tumači osjećaj neranjivosti kao kognitivnu pristranost koja negativno utječe na donošenje odluka, i to ne samo kod adolescenta već i kod osoba odrasle dobi (Millstein i Halpern-Felsher, 2002; Weinstein i Klein, 1996). Veže se uz optimističnu pristranost, općenito definiranu kao svojevrsnu kognitivnu pogrešku koja kod osobe inducira osjećaj neranjivosti u procesu donošenja odluka (u prvom redu kada se procjenjuju negativni i štetni ishodi u budućnosti). U tom procesu dolazi do specifične usporedbe s drugima. Osoba procjenjuje da bi, kada bi se upustila u određena rizična ponašanja (npr. pušenje), u budućnosti imala veću šansu doživjeti više pozitivnih, a manje negativnih ishoda u odnosu na druge ljude. Takva se pristranost može izrazito nepovoljno odraziti na pojedinca i njegovu dobrobit jer osoba precjenjuje pozitivne, a podcjenjuje negativne posljedice (npr. dobivanje raka) te u skladu s tim nije osobito motivirana uključiti se u određena zaštitna ponašanja.

Razvojni pristup razumijevanju osjećaja neranjivosti ide u dva smjera. Prvi od njih tretira osjećaj neranjivosti kao posljedicu jedne vrste kognitivne pogreške koja se javlja pri prijelazu u stadij formalnih operacija (12 godina), tzv. diferencijacijske pogreške (Elkind, 1967). Ona se očituje u slabu razlučivanju univerzalnih od jedinstvenih kategorija. Primjerice, adolescent misli da ljudi obolijevaju od raka ako puše više od 40 godina (univerzalni ishod), dok $u$ isto vrijeme smatra da on sam neće oboljeti od raka ako puši više od 40 godina (jedinstveni ishod). Dakle, diferencijacijska se pogreška očituje u vjerovanju da za sva rizična ponašanja vrijede univerzalni principi i njihove posljedice, osim na nas same. Takav pristup zagovaran je još u Elkindovoj teoriji adolescentskog egocentrizma (1967) u kojoj se pretpostavlja da adolescent percipira da su njegova iskustva i doživljaji jedinstveni i neponovljivi te ih stoga drugi ne mogu razumjeti jer za njih vrijede univerzalni ishodi.

Drugi smjer u razvojnom pristupu interpretira osjećaj neranjivosti kao adaptivan odgovor na proces separacije-individuacije tijekom razvoja mlade osobe. Taj proces očituje se u smanjenju ovisnosti o roditeljima i postupnu formiranju vlastitog identiteta, vrijednosti i uvjerenja da bi se u konačnici razvili u samostalnu osobu. Taj pristup ne gleda na neranjivost kao na diferencijacijsku pogrešku, već kao adaptivan odgovor na razvojne izazove separacije-individuacije (Lapsley, Fitzgerald, Rice i Jackson, 1989). Dakle, taj osjećaj nije rezultat pogreške kognitivnog razvoja, već razvoja ega. lako oba razvojna pristupa polaze od teze da je osjećaj neranjivosti ishod normativnog (uobičajenog) razvojnog procesa pojedinca, razlikuju se u pretpostavljenim implikacijama koje osjećaj neranjivosti ima na adaptivno funkcioniranje. Taj pristup, osim što smatra da osjećaj neranjivosti predviđa rizična ponašanja, pretpostavlja i predviđa pozitivne ishode za dobrobit pojedinca, odnosno njegovu prilagodbu, suočavanje i otpornost na stres (Aalsma, Lapsley i Flannery, 2006). Naime, pretpostavlja se da određeni stupanj osjećaja neranjivosti na neki način osnažuje 
adolescente u razvojnom periodu u kojem se nalaze, u suočavanju s novim razvojnim zadatcima. Istraživanje identiteta, sklapanje prijateljstava, učenje novih vještina, uspostavljanje romantičnih veza - sve to zahtijeva spremnost na upuštanje u nove situacije čiji je ishod nepoznat, drugim riječima - spremnost na upuštanje u određeni rizik. Upuštanje u rizike nekada će dovesti do uspješnijeg nošenja s novim situacijama i razvojnim zadatcima, a nekada do manje uspješna. No, čak i doživljaji neuspjeha adolescente pripremaju za preuzimanje izazova koji su pred njima prelaskom u odraslu dob (Lapsley i Hill, 2010). Ukratko, ta perspektiva ističe i potencijalne adaptivne funkcije osjećaja neranjivosti.

Empirijski su nalazi pokazali da osjećaj neranjivosti kod adolescenata predviđa s jedne strane niz rizičnih ponašanja, a s druge strane određene pozitivne razvojne ishode (npr. osjećaj vlastite vrijednosti, suočavanje usmjereno na problem, pokazatelje dobre prilagodbe; prema Lapsley, 2003). Navedene različite teorijske perspektive i divergentni empirijski nalazi pružili su poticaj za preispitivanje postavke o osjećaju neranjivosti kao jednodimenzionalnom konstruktu s jednostavnim ( $\mathrm{i}$ isključivo negativnim) implikacijama. Prema Lapsley (2003), takvi nalazi upućuju na to da osjećaj neranjivosti ima dvije strane. Jedna bi bila rizični čimbenik za ponašanja ugrožavajući za zdravlje; druga bi bila povezana s pozitivnim aspektima mentalnog zdravlja adolescenata. Mogućnost teorijske integracije tih različitih strana osjećaja neranjivosti proizišla je dalje iz ideje da se konceptualiziraju kao različite dimenzije tog fenomena i promatraju kao zasebni konstrukti.

Pri tome teorijski i logički ima smisla razlikovati osjećaj, tj. percepciju vlastite podložnosti mogućim prijetnjama ili šteti fizičkog karaktera, od percepcije vlastite podložnosti prijetnjama koje su više subjektivne prirode (proizlaze iz subjektivnih procjena značenja neke situacije za osobu). Ključna bi razlika bila što u prvom slučaju nerealne procjene mogu povećati spremnost na objektivno štetna ponašanja, posebice za tjelesno zdravlje. $U$ drugom slučaju, čak i pristrane procjene mogu predstavljati osobne psihološke resurse pa i tzv. "pozitivne iluzije" koje se vezuju za niz kriterija pozitivnih aspekata mentalnog zdravlja. Prema Taylor i Gollwitzer (1995) neki od tih kriterija uključuju pozitivan odnos prema samome sebi, sposobnost za produktivno i kreativno djelovanje, te sposobnost za brigu o drugim ljudima i učinkovito nošenje sa stresom.

Malo je instrumenata u kojima je neranjivost konceptualizirana na takav sveobuhvatniji način. No, uzimajući u obzir i opisani razvojni pristup, koji na neranjivost gleda kao na mogući adaptivni mehanizam, Lapsley i Hill (2010) razvili su skalu subjektivne neranjivosti (engl. Adolescent Invulnerability Scale; AIS) koja se sastoji od dvije supskale: a) neranjivosti na opasnost (dalje u tekstu: fizička neranjivost) koja se odnosi na osjećaj osobne "neuništivosti“ u suočavanju s fizičkim/ tjelesnim rizicima; te b) psihološke neranjivosti koja se odnosi na osjećaj nepokolebljivosti pred psihološkim ili osobnim neprilikama (engl. distress). To je jedan od najčešće korištenih instrumenata $\mathrm{u}$ istraživanjima osjećaja neranjivosti na adolescentskoj populaciji.

Prema razvojnom pristupu razumijevanja osjećaja neranjivosti taj bi se osjećaj trebao početi povećavati u razdoblju rane adolescencije (Hill, Duggan i Lapsley, 2012). Međutim, mali je broj empirijskih istraživanja ispitivao te pretpostavke. Morrell, Lapsley i Helpern-Felsher (2016) utvrdili su povećavanje osjećaja psihološke neranjivosti na uzorku četrnaestogodišnjaka u razdoblju od šest mjeseci dok se fizička neranjivost tijekom tog razdoblja nije statistički značajno povećala. Istraživanjima u kojima se neranjivost mjerila kao jednodimenzionalni konstrukt, utvrđeno je 
Marija Milić, Ružica-Marija Vlajčić, Valerija Križanić: Percepcija neranjivosti, upuštanje u rizična...

povećanje ovog osjećaja tijekom razdoblja rane i srednje adolescencije. Aalsma, Lapsley i Flannery (2006) te Alberts, Elkind i Ginsberg (2007) utvrdili su značajno veći osjećaj neranjivosti učenika u razdoblju srednje adolescencije $u$ odnosu na one $u$ ranoj adolescenciji (iako su se $u$ istraživanjima koristili različitim instrumentima procjene osjećaja neranjivosti). Millstein i Halpern-Felsher (2002) navode da su istraživanja odnosa osjećaja neranjivosti u adolescenciji i odrasloj dobi iznimno rijetka te da ona koja su i provedena, daju kontradiktorne nalaze. Sami autori istraživanjem su ustanovili da odrasli mladi imaju veću percepciju osjećaja neranjivosti od adolescenata, ali da je sam razvoj tog osjećaja tijekom adolescencije i odrasle dobi još uvijek nedovoljno istražen.

U usporedbi s dobnim razlikama, nešto su više istraživane spolne razlike u osjećaju neranjivosti. Mladići procjenjuju da su fizički i psihološki neranjiviji od djevojaka (Lapsley i Hill, 2010). Zanimljivo je da se mladići i djevojke ne razlikuju u pristranosti optimizma, ali se razlikuju kada je riječ o fizičkoj i psihološkoj neranjivosti. Ovi podatci idu u prilog dokazu da su neranjivost i pristran optimizam dva različita konstrukta (Lapsley i Hill, 2010). Subjektivna neranjivost ima adaptivnu funkciju u prilagodbi mladih na izazove na koje nailaze u socijalnoj i psihološkoj tranziciji u razdoblju prelaska u odraslu dob. Ako je to doista tako, onda je moguće da se mladići s pomoću osjećaja neranjivosti lakše od djevojaka suočavaju sa stresom koji se može javiti u tom razdoblju (Lapsley i Hill, 2010).

Prilikom procjena uspješnosti nošenja sa stresom, mladići se procjenjuju kao uspješniji u odnosu na djevojke. Roothman, Kirsten i Wissing (2003) smatraju da je to posljedica implicitnih, tradicijom nastalih uvjerenja o karakteristikama maskulinosti i femininosti. Odlike maskulinosti su kompetitivnost, neustrašivost, neranjivost (Good, Sherrod i Dillon, 2000), a što su sve karakteristike individualističkog identiteta (Nolen-Hoeksema i Rusting, 1999). U skladu s tim, mladići se koriste upravo tim sposobnostima prilikom suočavanja sa stresom i stresnim situacijama. Stoga se smatra da će se muškarci visoko procjenjivati na tim (maskulinim) odlikama da bi izbjegli unutarnji konflikt sa svojom rodnom ulogom (Roothman i sur. 2003). Za razliku od muškaraca, žene su usmjerenije na interpersonalne odnose i duhovnost (Roothman i sur., 2003) te im neranjivost nije važna za procjenu i potvrdu vlastita identiteta.

Lapsley i Hill (2010) upitnikom AIS (The Adolescent Invulnerability Scale) ispitali su postavke o postojanju dviju vrsta neranjivosti, odnosno razlike između neranjivosti uključene u rizična ponašanja (fizička neranjivost) i one uključene u ponašanja koja se povezuju s uspješnom prilagodbom (psihološka neranjivost). Istraživanje su proveli na uzorku osoba koje su bile na prelasku u odraslu dob (mladi odrasli). Rezultati na objema skalama neranjivosti bili su pozitivno povezani s rizičnim ponašanjem i zlouporabom opojnih sredstava, pri čemu je fizička neranjivost bila snažnije povezana s tim ponašanjima u odnosu na psihološku. S druge strane, osobe koje su bile psihološki neranjivije, imale su manje problema u samopoštovanju i problema s depresijom te manje interpersonalnih problema. Fizička neranjivost bila je jedino pozitivno povezana s interpersonalnim problemima, ali ne i s problemima povezanim s depresijom i sa samopoštovanjem. Hill, Duggan i Lapsley (2012) potvrdili su te nalaze $u$ istraživanju sa sudionicima u razdoblju rane adolescencije. Istraživanjem su potvrdili pozitivnu povezanost fizičke neranjivosti s delinkvencijom te s učestalošću konzumacije opojnih sredstava. Psihološka je neranjivost bila pozitivno povezana s uspješnom prilagodbom i kompetentnošću (aspektima psihološke dobrobiti), kao i rjeđom pojavom depresivnih simptoma. Za razliku od psihološke, fizička neranjivost nije bila značajna prediktivna varijabla kriteriju psihološke 
dobrobiti. Hill i sur. (2012) navode da ti nalazi podupiru postavku o mogućem pozitivnom djelovanju neranjivosti u razdoblju adolescencije s obzirom da ona može pomoći uspješnijoj prilagodbi i formiranju identiteta.

Sve jasnija potreba da se modeli zdravlja i prilagodbe konceptualiziraju sveobuhvatnije te da se u njih uključe i negativni i pozitivni indikatori (Antaramian, Huebner i Valois, 2008) vidljiva je i u istraživačkim trendovima. Ispitivanja samoprocjene zadovoljstva životom kod adolescenata u novije vrijeme zadobivaju sve više pažnje (Huebner, 2004). Zadovoljstvo životom definira se kao subjektivna procjena kvalitete vlastita života u cjelini i/ili u specifičnim životnim domenama (Diener, Suh, Lucas i Smith, 1999) te je jedan od aspekata subjektivne dobrobiti osobe. S obzirom na brojne promjene tijekom razdoblja adolescencije, bolja ili slabija prilagodba na nove ciljeve i izazove mogla bi imati znatne efekte na zadovoljstvo životom adolescenata. Nizom studija pokazano je da je uspješno ostvarivanje razvojnih zadataka kod mladih i zadovoljstvo u specifičnim životnim domenama (poput akademskog uspjeha, romantičnih veza, karijere) povezano s većim globalnim procjenama zadovoljstva životom (Kriesi i Buchmann, 2012; Räikkönen, Kokko, Chen i Pulkkinen, 2012; Salmela-Aro, Ek, Taanila i Chen, 2012; Schoon, Martin i Ross, 2012; Schulenberg, Bryant i O'Malley, 2004). Ukratko, prema Goldbeck, Schmitz, Besier, Herschbach i Henrich (2007) zadovoljstvo životom relevantna je varijabla koja nam može pružiti širu sliku o pitanju uspjeha u suočavanju s razvojnim izazovima i zadatcima kod adolescenata.

Svjetska zdravstvena organizacija istraživanjem zdravstvenih ponašanja mladih (engl. Health Behaviour in School-aged Children; HBSC) svake četiri godine prikuplja podatke o zadovoljstvu životom mladih između 11 i 15 godina u više od četrdeset sjevernoameričkih i europskih zemalja (HBSC, 2016). Rezultati tog istraživanja pokazali su da se zadovoljstvo životom kod adolescenata smanjuje s dobi i kod mladića i kod djevojaka, ali da mladići općenito izvještavaju o višim razinama zadovoljstva životom nego djevojke (HBASC, 2016). Analizirajući podatke HBSC studije OttováJordan i sur. (2015) pronašli su različite tendencije o pitanju zadovoljstva životom u različitim zemljama. Primjerice, u zemljama poput Danske, Finske i Norveške utvrđen je linearni porast zadovoljstva životom, u Austriji, Kanadi ili Škotskoj uočen je trend u obliku U krivulje u zadovoljstvu životom, dok u zemljama poput Grčke, Hrvatske ili Španjolske kohorte sudionika pokazuju jasno opadanje zadovoljstva životom (Ottová-Jordan i sur., 2015). Autori su te nalaze pripisali kontekstualnim razlikama, poput drukčijeg skupa očekivanja u životnom okruženju (obitelj, vršnjaci, škola) ili specifičnosti zemlje u kojoj osoba živi (npr. ekonomska situacija, društvena (ne)sigurnost, stopa nezaposlenosti i sl.), što sve može pridonijeti razini stresa, brige oko budućnosti i odraziti se na zadovoljstvo životom općenito, kao i različitim područjima života.

Unatoč tomu što se smatra jednim od indikatora kvalitete života osobe (kao osobna evaluacija životnih ishoda; prema Veerhoven, 2000), zadovoljstvo životom prediktor je i nekolicine drugih ishoda. Pronađeno je da je ta varijabla značajan prediktor razvoja depresivnih poremećaja i suicidalne ideacije kod adolescenata (Hawkins, Hawkins i Seeley, 1992; Park, Hoo i Schepp, 2005). Prema nalazima ranijih studija globalne procjene zadovoljstva životom pokazale su se i kao prediktori zlouporabe opojnih tvari (Newcomb, Bentler i Collins, 1986; Zullig, Valois, Hubner, Oeltmann i Drane, 2001), samoubojstava (Koivumaa-Honkanen, Honkanen, Viinamaki, Heikkila, Kaprio i Koskenvuo, 2001) i smrtnih slučajeva zbog fatalnih ozljeda (Koivumaa-Honkanen, Honkanen, Koskenvuo, Viinamaki i Kaprio, 2002). Korelacijska priroda istraživanja ipak ne omogućava zaključke 
o tome je li nezadovoljstvo životom determinanta ponašanja poput zlouporabe opojnih sredstava ili je zapravo posljedica takva zdravstveno rizičnog ponašanja (npr. Zullig i sur., 2001). No, važnost istraživanja zadovoljstva životom kod adolescenata dodatno su podcrtale longitudinalne studije, pokazavši da niska razina zadovoljstva životom predviđa kasnije eksternalizirane i internalizirane probleme te iskustva vršnjačke viktimizacije (Haranin, Huebner i Suldo, 2007; Martin, Huebner i Valois, 2008) te da je za adolescente izrazito zadovoljne svojim životom manje vjerojatno da će kasnije, nakon značajnih životnih stresora, pokazivati eksternalizirane probleme u ponašanju (Suldo i Huebner, 2004). S obzirom na takve nalaze, prema Antaramian i sur. (2008), zadovoljstvo životom može se promatrati i kao svojevrstan osnažujući čimbenik koji može facilitirati prilagodbi novim ciljevima i situacijama koje nosi odrastanje.

Unatoč tumačenjima neranjivosti u kontekstu ponašanja adolescenata još uvijek ne postoji konsenzus o konstruktu osjećaja neranjivosti, kao ni implikacijama koje ima za taj razvojni period (Aalsma, Lapsley i Flannery, 2006; Lapsley i Hill, 2010). Stoga se ovim radom nastoji dati doprinos razumijevanju ove teme daljnjim istraživanjem "dvojne prirode" osjećaja neranjivosti. Dosadašnji empirijski dokazi ovako postavljena koncepta neranjivosti temeljili su se na rezultatima utvrđenim već spomenutim AIS upitnikom (Lapsley i Hill, 2010), stoga provjera ovog konstrukta drugim, sličnim instrumentima može pružiti dodatnu potvrdu njegove utemeljenosti. Utvrde li se i drugim instrumentarijem (korištenim u ovoj studiji) drukčiji obrasci povezanosti fizičke i psihološke neranjivosti s različitim ponašanjima i procjenama zadovoljstva životom, bit će to još jedan prilog utemeljenosti gledišta o "dvojnoj prirodi" neranjivosti. Nadalje, ovim se radom nastoje nadopuniti dosadašnji nalazi o vezi osjećaja fizičke neranjivosti i upuštanja u zdravstveno rizična ponašanja mladih. Pri tome će se razmotriti mogu li osjećaji neranjivosti pridonijeti razumijevanju kvalitativnih razlika među adolescentima u iskustvima upuštanja u rizična ponašanja, ali i razlika u intenzitetu tog ponašanja (učestalosti). I konačno, u radu se slijedi teza da osjećaj neranjivosti nije samo rezultat kognitivne pogreške već da se u njegovoj podlozi nalaze složeniji sustavi koji su u funkciji psihološke zaštite i/ili osnaživanja pojedinca u ponašanjima korisnim za ostvarivanje psihosocijalnih ciljeva svojstvenih adolescentskoj dobi (pa i njegove pripreme za ulazak u odraslu dob). Ta se teza provjerava uvođenjem pokazatelja povoljnih aspekata prilagodbe (zadovoljstva životom i različitim područjima života) te analizom njihovih odnosa s osjećajem neranjivosti. Doprinos ovog istraživanja također je i u ispitivanju odnosa psihološke neranjivosti s jednim od aspekata subjektivne dobrobiti (zadovoljstvom životom) s obzirom da su dosadašnja istraživanja psihološku neranjivost, u većini slučajeva, povezivala s psihološkom dobrobiti (npr. samopoštovanjem, interpersonalnim odnosima; Hill, Duggan i Lapsley, 2012; Lapsley i Hill, 2010).

\section{Cilj, istraživački problemi i hipoteze}

U skladu s navedenim, cilj je ovoga rada istražiti dva aspekta osjećaja neranjivosti (fizičke i psihološke) na uzorku srednjoškolaca i odnos tih aspekata neranjivosti s upuštanjem u rizična ponašanja s jedne strane te pokazateljima subjektivne dobrobiti s druge strane.

Nekoliko je specifičnijih istraživačkih problema. Prvo, ispitati odnos osjećaja fizičke i psihološke neranjivosti te dobi, spola i zadovoljstva specifičnim područjima života. Očekujemo da će procjene fizičke i psihološke neranjivosti biti veće kod starijih sudionika, kao i mladića u usporedbi 
s djevojkama. Polazeći od teze da fizička i psihološka neranjivost predstavljaju povezane, ali različite konstrukte, očekujemo da će imati i drukčije obrasce povezanosti s mjerama zadovoljstva specifičnim područjima života.

Drugi je problem ispitati na koji način percepcija fizičke i psihičke neranjivosti doprinosi čestini konzumiranja cigareta kod srednjoškolaca, a zatim i kako doprinose njihovu općem zadovoljstvu životom. S obzirom da se osjećaj fizičke neranjivosti više povezuje s rizičnim ponašanjem, a osjećaj psihološke neranjivosti s povoljnim razvojnim aspektima odrastanja, očekujemo da će fizička neranjivost biti snažniji prediktor čestine pušenja, a psihološka snažniji prediktor općeg zadovoljstva životom.

Treći je problem provjeriti razlikuju li se srednjoškolci s kvalitativno drukčijim iskustvima upuštanja u rizična ponašanja konzumiranja cigareta u osjećaju neranjivosti. Polazeći od pretpostavke da osjećaj fizičke neranjivosti predstavlja rizični čimbenik za započinjanje pušenja, očekujemo da će taj osjećaj biti najmanje izražen kod srednjoškolaca koji nikada nisu ni probali pušiti, nešto više kod onih koji su se u to ponašanje uključili jednokratno/eksperimentalno, a najviše kod onih koji redovito konzumiraju cigarete. Sagledavajući psihološku neranjivost kao mogući osobni resurs uz koji se osoba uspješnije nosi sa stresom ili odupire socijalnom pritisku (neki od razloga za započinjanje pušenja), očekujemo da će biti najizraženija kod onih koji se nikada nisu upustili u to ponašanje, u odnosu na ostale skupine.

\section{Metoda}

\section{Sudionici}

U ovom su radu analizirani podatci $N=297$ srednjoškolaca ( $n=161$ djevojaka) učenika drugog (29,1\%), trećeg (43,58 \%) i četvrtog (34,3\%) razreda iz različitih srednjih škola na području Slavonije. U istraživanju su sudjelovali učenici Medicinske škole Osijek ( $n=73)$, Gimnazije Đakovo $(n=88)$ i učenici trogodišnjih i četverogodišnjih smjerova Srednje strukovne škole Đakovo $(n=$ 136). Dobni raspon bio je od 16 do 20 godina $(M=17,33 ; S D=0,834)$. U uzorku je $26,9 \%$ učenika koji nisu nikada probali pušiti, a približno toliko, $24,9 \%$, ih je probalo pušiti, ali ne puše. Sudionika koji su pušili, ali su prestali je 7,1 \%, dok je učenika koji povremeno ili stalno puše $41,1 \%$.

\section{Instrumenti}

U svrhu ispitivanja osjećaja neranjivosti korištena je Skala osjećaja neranjivosti (Ćorić, Vlajčić, Goretić i Kolak, 2018). Skala se sastoji od 30 čestica koje su raspoređene u dvije supskale — fizička neranjivost (17 čestica) i psihološka neranjivost (13 čestica). Sudionici su na pitanja odgovarali na skali Likertova tipa od četiri stupnja, pri čemu 1 označava "uopće se ne slažem”, a 4 „u potpunosti se slažem". Ukupan rezultat na objema supskalama formira se kao prosječna vrijednost procjena na svim česticama. Raspon rezultata kreće se između jedan i četiri, pri čemu veći rezultat označava veću sklonost osjećaju (psihološke ili fizičke) neranjivosti. Primjeri čestica fizičke neranjivosti su: Mogao/la bih koristiti psihoaktivne supstance (droga, alkohol, nikotin) bez dugoročnih posljedica. Mogao/la bih se napiti bez da mi se dogodi nešto loše., a psihološke: Nisam osjetljiv/a na kritike koje mi drugi upućuju. Bojim se da neću uspjeti ostvariti sve svoje ciljeve. Pet čestica na supskali fizičke 
Marija Milić, Ružica-Marija Vlajčić, Valerija Križanić: Percepcija neranjivosti, upuštanje u rizična...

neranjivosti i tri čestice na skali psihološke neranjivosti obrnuto su formulirane. Koeficijent unutarnje konzistencije Cronbach alpha u ovom istraživanju pokazao je zadovoljavajuću pouzdanost od ,82 za supskalu fizičke neranjivosti i, 75 za supskalu psihološke neranjivosti.

Indeks osobne dobrobiti (International Wellbeing Group, 2013 hrvatski prijevod Kaliterna Lipovčan, 2011) jedna je od češće korištenih skala za ispitivanje zadovoljstva životom (Kovčo Vukadin, Novak i Križan, 2016). Skalom se ispituje zadovoljstvo u sedam životnih domena (životni standard, zdravlje, postignuća, odnosi s bližnjima (obitelji i prijateljima), osjećaj sigurnosti, pripadanje zajednici i sigurnost u budućnost), a sadrži i pitanje vezano za zadovoljstvo životom općenito. Svaka od domena, kao i opće zadovoljstvo životom, mjeri se s jednom česticom tako da se upitnik sastoji od sveukupno osam čestica. Odgovore daju na skali Likertova tipa od 11 stupnjeva pri čemu 0 označuje odgovor "nimalo nisam zadovoljan", a 10 "u potpunosti sam zadovoljan".

Konzumiranje cigareta ispitano je dvama pitanjima. Prvo pitanje Koja se od sljedećih tvrdnji odnosi na Vas? — vezano je uz generalnu prisutnost navike konzumiranja cigareta (Fidler, Wardle, Henning Broderson, Jarvis i West, 2006). Sudionici su trebali označiti jednu od ponuđenih tvrdnji, među kojima su: puše li više od šest cigareta tjedno; jednu do šest cigareta tjedno; puše li ponekad, ali ne više od jedne cigarete tjedno; jesu li prije pušili, ali prestali; ili probali samo jedanput cigarete; ili da nikad nisu pušili cigarete. Navedeno je pitanje postavljeno da bi se diferencirale skupine sudionika s kvalitativno drukčijim iskustvima upuštanja u takav oblik rizična ponašanja. $\mathrm{Na}$ temelju odgovora na ovo pitanje, izdvojene su četiri kategorije iskustva sudionika: 1) "nikada nisu probali pušiti"; 2) "probali su, ali ne puše"; 3) "prestali su pušiti"; i 4) "puše" (u slučajevima gdje je zaokružena bilo koja od prvih triju tvrdnja). Na drugo pitanje: Koliko često konzumirate cigarete? (Kalebić-Maglica i Dorčić, 2015) sudionici su odgovarali na skali od 5 stupnjeva (1 - nikada do 5 — svaki dan) gdje viši rezultat upućuje na učestaliju konzumaciju cigareta. Varijabla formirana na temelju drugog pitanja o navikama pušenja u ovom je istraživanju korištena kao kriterijska varijabla kod statističke analize vezane za drugi istraživački problem, referirajući se na pristup u navedenom radu (Kalebić-Maglica i Dorčić, 2015).

\section{Postupak}

Istraživanje je odobrilo Etičko povjerenstvo Filozofskog fakulteta u Osijeku. Provedeno je skupno na početku ili na kraju školskog sata, a samo ispunjavanje upitnika trajalo je oko 20 minuta. Učenicima je objašnjena svrha istraživanja te je naglašeno da je istraživanje anonimno i dobrovoljno te da mogu odustati od sudjelovanja u bilo kojem trenutku. Također, sudionicima je rečeno da će se dobiveni podatci koristiti isključivo u istraživačke svrhe i obrađivati na skupnoj razini.

Kada su svi sudionici ispunili upitnike, zahvalili smo im na sudjelovanju te su im podijeljeni letci o štetnim posljedicama ovisnosti o pušenju.

\section{Rezultati}

Prije provedbe statističkih analiza relevantnih za istraživačke probleme, u Tablici 1. prikazani su deskriptivni pokazatelji za kvantitativne varijable uključene u daljnje analize. 
Kriminologija i socijalna integracija Vol 27 (2019) 2, 151 - 176.

Tablica 1. Deskriptivna statistika glavnih varijabli u istraživanju $(N=297)$

\begin{tabular}{|l|c|c|c|c|c|c|}
\cline { 2 - 6 } \multicolumn{1}{c|}{} & M & SD & $\begin{array}{c}\text { Opaženi } \\
\text { minimum }\end{array}$ & $\begin{array}{c}\text { Opaženi } \\
\text { maksimum }\end{array}$ & $\begin{array}{c}\text { Teorijski } \\
\text { minimum }\end{array}$ & $\begin{array}{c}\text { Teorijski } \\
\text { maksimum }\end{array}$ \\
\hline Fizička neranjivost & 2,12 & 0,545 & 1,06 & 3,81 & 1,00 & 4,00 \\
\hline Psihološka neranjivost & 2,75 & 0,474 & 1,38 & 4,00 & 1,00 & 4,00 \\
\hline Pušenjea & 2,35 & 1,648 & 1 & 5 & 1 & 5 \\
\hline Zadovoljstvo životom općenito & 7,48 & 2,296 & 0 & 10 & 0 & 10 \\
\hline Zadovoljstvo: & & & & & & \\
\hline - životnim standardom & 7,99 & 1,936 & 0 & 10 & 0 & 10 \\
\hline - zdravljem & 8,08 & 2,003 & 0 & 10 & 0 & 10 \\
\hline - postignućima & 7,51 & 2,070 & 0 & 10 & 0 & 10 \\
\hline - odnosima s bližnjima & 8,22 & 2,159 & 0 & 10 & 0 & 10 \\
\hline - osjećajem sigurnosti & 8,24 & 2,038 & 0 & 10 & 0 & 10 \\
\hline - osjećajem pripadanja zajednici & 7,77 & 2,405 & 0 & 10 & 0 & 10 \\
\hline - osjećajem sigurnosti u budućnost & 7,21 & 2,438 & 0 & 10 & 0 & 10 \\
\hline
\end{tabular}

Napomene: M — aritmetička sredina; SD — standardna devijacija; a Varijabla „Pušenje” obuhvaća odgovore na pitanje Koliko često konzumirate cigarete?

Da bi se ispitala međusobna povezanost varijabli ispitanih istraživanjem izračunani su koeficijenti korelacija među tim varijablama (Tablica 2.).

Tablica 2. Korelacije varijabli uključenih u istraživačke probleme $(N=297)$

\begin{tabular}{|c|c|c|c|c|c|c|c|}
\hline & Spol & $\begin{array}{c}\text { Fizička } \\
\text { neranjivost }\end{array}$ & $\begin{array}{l}\text { Psihološka } \\
\text { neranjivost }\end{array}$ & Pušenje & $\begin{array}{l}\text { Zadovoljstvo } \\
\text { životom } \\
\text { općenito }\end{array}$ & $\begin{array}{l}\text { Zadovoljstvo } \\
\text { životnim } \\
\text { standardom }\end{array}$ & $\begin{array}{c}\text { Zadovoljstvo } \\
\text { zdravljem }\end{array}$ \\
\hline Dob &,- 20 ** &, $22^{\star *}$ &, $17^{\star \star}$ &, $21^{* *}$ &, 06 &,- 03 &,- 11 \\
\hline Spol & &,$- 43^{* *}$ &,$- 30^{* *}$ &,- 06 &,- 09 &,- 10 &,- 11 \\
\hline $\begin{array}{c}\text { Fizička } \\
\text { neranjivost }\end{array}$ & & &, $42^{* *}$ &, $45^{* *}$ &,- 05 &,- 04 &,$- 12^{\star}$ \\
\hline $\begin{array}{l}\text { Psihološka } \\
\text { neranjivost }\end{array}$ & & & &, $15^{* *}$ &, $32^{\star *}$ & $32^{* *}$ & $23^{* *}$ \\
\hline Pušenje & & & & &,- 06 &,- 01 &,$- 20^{\star *}$ \\
\hline $\begin{array}{l}\text { Zadovoljstvo } \\
\text { životom } \\
\text { općenito }\end{array}$ & & & & & &, $62^{\star *}$ &, $38^{\star *}$ \\
\hline $\begin{array}{l}\text { Zadovoljstvo } \\
\text { životnim } \\
\text { standardom }\end{array}$ & & & & & & &, $30^{* *}$ \\
\hline $\begin{array}{c}\text { Zadovoljstvo } \\
\text { zdravljem }\end{array}$ & & & & & & & \\
\hline $\begin{array}{l}\text { Zadovoljstvo } \\
\text { postignućima }\end{array}$ & & & & & & & \\
\hline $\begin{array}{l}\text { Zadovoljstvo } \\
\text { odnosima s } \\
\text { bližnjima }\end{array}$ & & & & & & & \\
\hline $\begin{array}{l}\text { Zadovoljstvo } \\
\text { osjećajem } \\
\text { sigurnosti }\end{array}$ & & & & & & & \\
\hline $\begin{array}{c}\text { Zadovoljstvo } \\
\text { osjećajem } \\
\text { pripadanja } \\
\text { zajednici }\end{array}$ & & & & & & & \\
\hline
\end{tabular}


Marija Milić, Ružica-Marija Vlajčić, Valerija Križanić: Percepcija neranjivosti, upuštanje u rizična...

\begin{tabular}{|c|c|c|c|c|c|}
\hline & $\begin{array}{l}\text { Zadovoljstvo } \\
\text { postignućima }\end{array}$ & $\begin{array}{c}\text { Zadovoljstvo } \\
\text { odnosima s } \\
\text { bližnjima }\end{array}$ & $\begin{array}{c}\text { Zadovoljstvo } \\
\text { osjećajem } \\
\text { sigurnosti }\end{array}$ & $\begin{array}{c}\text { Zadovoljstvo } \\
\text { osjećajem } \\
\text { pripadanja } \\
\text { zajednici }\end{array}$ & $\begin{array}{l}\text { Zadovoljstvo } \\
\text { osjećajem } \\
\text { sigurnosti u } \\
\text { budućnost }\end{array}$ \\
\hline Dob &, $13^{*}$ & ,05 &, $17^{\star *}$ & ,07 & ,08 \\
\hline Spol & $-18^{\star *}$ &,- 04 &,$- 16^{* *}$ &,- 03 &,$- 24^{* *}$ \\
\hline $\begin{array}{c}\text { Fizička } \\
\text { neranjivost }\end{array}$ & ,03 &,- 09 & ,04 &,- 02 &, $12^{\star}$ \\
\hline $\begin{array}{l}\text { Psihološka } \\
\text { neranjivost }\end{array}$ &, $45^{\text {** }}$ &, $24^{\star \star}$ &, $35^{\star \star}$ &, $22^{\star \star}$ &, $48^{\star \star}$ \\
\hline Pušenje &,- 06 &,- 03 &,- 04 &,- 01 & ,02 \\
\hline $\begin{array}{l}\text { Zadovoljstvo } \\
\text { životom } \\
\text { općenito }\end{array}$ &, $70^{\star *}$ &, $56^{\star \star}$ &, $50^{\star \star}$ &, $57^{\star \star}$ &, $56^{\star \star}$ \\
\hline $\begin{array}{l}\text { Zadovoljstvo } \\
\text { životnim } \\
\text { standardom }\end{array}$ &, $46^{\star \star}$ &, $46^{\star *}$ &, $39^{\star \star}$ &, $43^{\star *}$ &, $42^{\star \star}$ \\
\hline $\begin{array}{l}\text { Zadovoljstvo } \\
\text { zdravljem }\end{array}$ &, $35^{\star \star}$ &, $22^{\star \star}$ & ,39** &, $28^{\star \star}$ &, $34^{\star \star}$ \\
\hline $\begin{array}{l}\text { Zadovoljstvo } \\
\text { postignućima }\end{array}$ & &, $51^{\star \star}$ & $47^{\star \star}$ &, $50^{\star \star}$ &, $57^{\star \star}$ \\
\hline $\begin{array}{c}\text { Zadovoljstvo } \\
\text { odnosima s } \\
\text { bližnjima }\end{array}$ & & & $45^{\star \star}$ &, $51^{\star \star}$ &, $40^{\star \star}$ \\
\hline $\begin{array}{c}\text { Zadovoljstvo } \\
\text { osjećajem } \\
\text { sigurnosti }\end{array}$ & & & &, $52^{\star \star}$ &, $51^{\star \star}$ \\
\hline $\begin{array}{c}\text { Zadovoljstvo } \\
\text { osjećajem } \\
\text { pripadanja } \\
\text { zajednici }\end{array}$ & & & & &, $44^{\star \star}$ \\
\hline
\end{tabular}

Napomene: a varijabla „Pušenje“ obuhvaća odgovore na pitanje Koliko često konzumirate cigarete? ${ }^{*} \mathrm{p}<, 05 ;{ }^{* *} \mathrm{p}<, 01$; varijabla "Spol" kodirana je na sljedeći način: 1 = mladići, 2 = djevojke

Kao što se iz Tablice 2. može vidjeti, fizička i psihološka neranjivost međusobno su umjereno povezane. Ta povezanost nije neobična s obzirom da mjere dva relativno bliska konstrukta, odnosno percepciju dvaju aspekata vlastite neranjivosti. Korelacije, iako postoje, nisu velike u mjeri da se ove varijable ne bi mogle uzimati u obzir zajedno u nekim daljnjim analizama. Na primjer, Field (2015) navodi da se prediktori u regresijskoj analizi ne bi trebali uvrštavati zajedno u analizu ako im je koeficijent korelacije veći od ,80. Iz Tablice 2. možemo iščitati i da postoji pozitivna povezanost čestine pušenja i dobi. Stariji sudionici istraživanja češće konzumiraju cigarete u odnosu na mlađe. Također, vidljiva je i pozitivna povezanost čestine pušenja i procjene na skalama fizičke i psihološke neranjivosti. Psihološka neranjivost je nisko, a fizička umjereno povezana s pušenjem.

U okviru prvoga istraživačkog problema željeli smo ispitati na koji su način ta dva aspekta neranjivosti povezana s dobi, spolom i zadovoljstvom specifičnim područjima života.

Koeficijenti korelacije prikazani u Tablici 2. pokazuju da su i osjećaj fizičke i psihološke neranjivosti nešto veći kod starijih sudionika ovog istraživanja. Varijabla spola također je značajno povezana s obama aspektima neranjivosti. Da bismo provjerili spolne razlike u procjenama neranjivosti, proveli 
smo dva t-testa i ustanovili da se mladići i djevojke značajno razlikuju u procjenama i fizičke $\left(t_{(295)}\right.$ $=8,247, p<, 01)$ i psihološke neranjivosti $\left(t_{(295)}=5,360, p<, 01\right)$, s time da se mladići procjenjuju fizički i psihološki neranjivijim do djevojaka (Tablica 3.).

Tablica 3. Procjene fizičke i psihološke neranjivosti kod mladića $(n=136)$ i djevojaka $(n=161)$

\begin{tabular}{|c|c|c|c|c|}
\cline { 2 - 5 } \multicolumn{1}{c|}{} & \multicolumn{2}{c|}{ Fizička neranjivost } & $\boldsymbol{M}$ & \multicolumn{2}{c|}{ Psihološka neranjivost } \\
\cline { 2 - 5 } \multicolumn{1}{c|}{} & $\boldsymbol{M}$ & SD & 2,90 & 0,458 \\
\hline Mladići & 2,38 & 0,542 & 2,62 & 0,449 \\
\hline Djevojke & 1,91 & 0,445 & \\
\hline
\end{tabular}

Nakon toga usporedili smo na koji su način ta dva aspekta neranjivosti povezana sa zadovoljstvom života sudionika istraživanja — općenito i u pojedinim sferama svojeg života. Psihološka neranjivost pozitivno je povezana s procjenama zadovoljstva sa svih sedam aspekata života kao is procjenom općeg zadovoljstva životom. Korelacije se kreću od niske kod zadovoljstva pripadanja zajednici do umjerene za osjećaj sigurnosti u budućnost. Odnosno, procjene zadovoljstva svim područjima života veće su kod onih sudionika istraživanja koji se osjećaju psihološki neranjivijim. $\mathrm{S}$ druge strane, osjećaj fizičke neranjivosti značajno je povezan samo s procjenama zadovoljstva u dvjema sferama života, odnosno u niskoj je negativnoj korelaciji sa zadovoljstvom zdravljem te $u$ niskoj pozitivnoj korelaciji s osjećajem sigurnosti u budućnost.

Da bismo u okviru drugog problema ispitali na koji način percepcija fizičke i psihičke neranjivosti doprinose objašnjenju različitih kriterijskih varijabli, rizičnog ponašanja (pušenja) i zadovoljstva životom, proveli smo dvije hijerarhijske regresijske analize. Prvo je provedena hijerarhijska regresijska analiza s kriterijem učestalosti pušenja (Tablica 4.). U prvi korak analize uvrštene su demografske varijable dob i spol te se jedino dob pokazala kao značajan prediktor učestalosti pušenja. U drugom koraku, u analizu su uvrštene fizička i psihološka neranjivost. Te dvije varijable objašnjavaju dodatnih 20,4 \% varijance. Fizička neranjivost pokazala se kao statistički značajan prediktor učestalosti pušenja, dok psihološka neranjivost nije. U drugom koraku spol, koji u prvom nije bio statistički značajan, postaje značajan što upozorava na mogući supresijski efekt ove varijable. Moguće da međusobna povezanost spola i fizičke neranjivosti $(r=-, 43)$ dovodi do ovakvog efekta.

Tablica 4. Rezultati hijerarhijske regresijske analize s čestinom pušenja kao kriterijskom varijablom te procjenama fizičke i psihološke neranjivosti kao prediktorima

\begin{tabular}{|c|c|c|}
\hline Prediktori & korak & \multicolumn{1}{|c|}{, $182^{\star *}$} \\
\hline Spol &,- 018 &, $137^{*}$ \\
\hline Dob &, $204^{\star *}$ &, $518^{\star *}$ \\
\hline Fizička neranjivost & &,- 034 \\
\hline Psihološka neranjivost & &, 247 \\
\hline &, 043 &, 204 \\
\hline F & 6,043 & $23,993^{\star *}$ \\
\hline
\end{tabular}

Napomene: ${ }^{*} p<, 05 ;{ }^{* \star} p<, 01 ;$ spol: 1 = mladići, 2 = djevojke 
Marija Milić, Ružica-Marija Vlajčić, Valerija Križanić: Percepcija neranjivosti, upuštanje u rizična...

Drugom regresijskom analizom željeli smo ispitati doprinos fizičke i psihološke neranjivosti općem zadovoljstvu životom (Tablica 5.).

Tablica 5. Rezultati regresijske analize s općim zadovoljstvom životom kao kriterijskom varijablom te procjenama fizičke i psihološke neranjivosti kao prediktorima

\begin{tabular}{|c|c|c|}
\hline Prediktori & korak & korak \\
\hline Spol &,- 078 &,- 074 \\
\hline Dob &, 043 &, 031 \\
\hline Fizička neranjivost & &,$- 263^{* *}$ \\
\hline Psihološka neranjivost & &, $404^{\star *}$ \\
\hline &, 009 &, 152 \\
\hline F &, 009 &, 142 \\
\hline
\end{tabular}

Napomene: ${ }^{* *} p<, 01 ;$ spol: $1=$ mladići, 2 = djevojke

Kao što se iz analize može vidjeti, obje su varijable značajni prediktori zadovoljstva životom, ali je fizička neranjivost negativni, a psihološka pozitivni (i veći) prediktor. Ta dva prediktora objašnjavaju $15 \%$ varijance općeg zadovoljstva životom. Budući da nije utvrđena značajna povezanost fizičke neranjivosti i zadovoljstva životom, a ovdje se fizička neranjivost pojavljuje kao značajan prediktor, provjerena je mogućnost pojave supresije na način da je iz drugog koraka regresijske analize ispušten prediktor psihološke neranjivosti. Fizička neranjivost samostalno uvrštena u drugom koraku regresijske analize ne pridonosi objašnjenju kriterijske varijable zadovoljstva životom, odnosno nije statistički značajan prediktor. Na osnovi tih podataka možemo zaključiti da se u regresijskoj analizi prikazanoj u Tablici 5. značajnost efekta fizičke neranjivosti može pripisati umjerenoj povezanosti koju ona ima sa psihološkom neranjivošću $(r=, 42, p<, 01)$. Nakon tih analiza, može se zaključiti da psihološka neranjivost doprinosi objašnjenju kriterija zadovoljstva životom, a fizička ne.

Da bi se u okviru trećeg problema provjerilo razlikuju li se procjene fizičke i psihološke neranjivosti kod sudionika koji imaju različita iskustva upuštanja u zdravstveno rizično ponašanje, sudionici su na temelju odabrane tvrdnje o iskustvu s konzumiranjem cigareta podijeljeni u četiri kategorije: one koji nisu nikada niti probali pušiti; one koji su samo probali; učenike koji su pušili, ali su prestali; te učenike koji povremeno ili stalno konzumiraju cigarete.

Kao što je vidljivo iz Tablice 2. spol i dob značajno su povezani s fizičkom i psihološkom neranjivošću. Stoga su u provjeri razlika koliko se učenici različitih iskustava u konzumiranju cigareta razlikuju u procjenama fizičke i psihološke neranjivosti, varijable spola i dobi uzete u obzir kao moguće kovarijate. Analizom je utvrđeno da je kovarijanca spola značajno povezana s fizičkom neranjivošću $\left(F_{(1,291)}=70,010, p<, 01\right)$, dok se kovarijanca dobi nije pokazala kao značajna $\left(F_{(1,291)}\right.$ $=1,891, p>, 05)$. Međutim, i nakon kontrole učinaka dobi i spola, procjene fizičke neranjivosti značajno se razlikuju među sudionicima s različitim iskustvima upuštanja u konzumaciju cigareta $\left(F_{(3,291)}=29,869, p<, 01\right)$. Gledajući pojedinačni doprinos varijable iskustva upuštanja u konzumaciju cigareta na procjenu fizičke neranjivosti, ona samostalno objašnjava 23,5 \% varijance (parcijalna $\eta^{2}$ $=, 235)$ rezultata, dok je samostalni doprinos spola 19,4\%. Pronađeni efekti mogu se okarakterizirati kao veliki s obzirom da je prema Cohenu (1988) veličina efekta od 0,01 mala, 0,06 srednja, a 0,14 i veća velika. Bonferronijevim post hoc testom utvrđeno je da se procjene sudionika koji nisu nikada probali pušiti statistički značajno razlikuju od svih ostalih skupina, odnosno oni imaju najniže procjene fizičke neranjivosti u usporedbi s ostalim skupinama. Sudionici koji su probali pušiti, 
ali ne puše i sudionici koji su prestali pušiti, ne razlikuju se u procjenama fizičke neranjivosti, ali se na jednak način (obje skupine) razlikuju od ostalih dviju skupina. Naime, procjenjuju svoju fizičku neranjivost značajno niže u odnosu na sudionike koji puše, a više u odnosu na sudionike koji nisu nikada probali pušiti. Sudionici koji puše procjenjuju se kao fizički neranjiviji od skupine sudionika koji nisu nikada ni probali pušiti i od sudionika koji su probali pušiti, ali ne puše.

U Tablici 6. prikazane su prosječne vrijednosti procjena neranjivosti u ovisnosti o iskustvu konzumiranja cigareta kod sudionika ovoga istraživanja.

Tablica 6. Procjene fizičke i psihološke neranjivosti kod sudionika različitog iskustva konzumiranja cigareta

\begin{tabular}{|c|c|c|c|c|c|c|}
\cline { 3 - 6 } \multicolumn{1}{c|}{} & N & M & SD & Minimum & Maksimum \\
\hline Fizička neranjivost & Nikada nisu probali pušiti & 80 & 1,75 & 0,425 & 1,06 & 3,13 \\
\hline \multirow{4}{*}{ Psihološka neranjivost } & Probali su, ali ne puše & 74 & 2,07 & 0,437 & 1,38 & 3,50 \\
\cline { 2 - 7 } & Prestali su pušiti & 21 & 2,25 & 0,471 & 1,44 & 3,19 \\
\cline { 2 - 7 } & Puše & 122 & 2,38 & 0,539 & 1,25 & 3,81 \\
\hline & Nikada nisu probali pušiti & 80 & 2,62 & 0,494 & 1,62 & 3,69 \\
\cline { 2 - 7 } & Probali su, ali ne puše & 74 & 2,76 & 0,438 & 1,38 & 3,62 \\
\cline { 2 - 7 } & Prestali su pušiti & 21 & 2,88 & 0,437 & 2,23 & 3,77 \\
\cline { 2 - 7 } & Puše & 122 & 2,81 & 0,474 & 1,77 & 4,00 \\
\hline
\end{tabular}

Za razliku od fizičke neranjivosti, razlike u psihološkoj neranjivosti među četirima skupinama srednjoškolaca koji se razlikuju u iskustvu konzumiranja cigareta, nakon kontrole efekata spola i dobi, nisu bile značajne $\left(F_{(3,291)}=2,043, p>, 05\right)$.

\section{Rasprava}

Cilj ovoga rada bio je istražiti dva aspekta osjećaja neranjivosti, fizičke i psihološke, na uzorku srednjoškolaca i odnos tih aspekata neranjivosti s upuštanjem u rizična ponašanja s jedne strane te pokazateljima subjektivne dobrobiti s druge strane.

Analizama je utvrđena pozitivna korelacija dobi i oba aspekta neranjivosti. Povezanosti su niske, ali upućuju na to da se s dobi povećava percepcija neranjivosti. Takvi nalazi u skladu su s pretpostavkama razvojnog pristupa razumijevanju osjećaja neranjivosti prema kojima taj osjećaj raste tijekom adolescencije (Hill, Duggan i Lapsley, 2012). Ranijim je istraživanjima utvrđeno da osjećaj neranjivosti raste u razdoblju između rane i srednje adolescencije (Aalsma i sur., 2006; Alberts i sur., 2007), a na osnovi nalaza utvrđenih ovim istraživanjem, možemo pretpostaviti da ova percepcija raste i tijekom razdoblja srednje adolescencije.

Provjera razlika u percepciji neranjivosti između mladića i djevojaka pokazala je da se mladići procjenjuju i fizički i psihološki neranjivijima u odnosu na djevojke. Ti su nalazi konzistentni s nekolicinom dosadašnjih studija (Aalsma i sur., 2006; Alberts, Elkind i Ginsberg, 2007; Lapsley i Hill, 2010). Jedno je od mogućih objašnjenja takvih nalaza način socijalizacije mladića i djevojaka kojima nastaju neke od značajnih razlika u ponašanju i doživljavanju (između ostalog i osjećaju neranjivosti). Šikić Mićanović (1997) navodi da se socijalizacijom mladići uče susprezati osjećaj boli, uči ih se da budu neranjivi i "čvrsti” te da što prije steknu autonomiju i neovisnost. Povećan osjećaj neranjivosti može se povezati i s činjenicom da mladići češće od djevojaka čine prekršaje 
Marija Milić, Ružica-Marija Vlajčić, Valerija Križanić: Percepcija neranjivosti, upuštanje u rizična...

(Bennett, Farrington i Huesmann, 2000; Ručević, 2011), pokazuju nepoželjna normativna ponašanja (Ručević, 2011) kao i da općenito manifestiraju više oblika delinkventnog ponašanja od djevojaka (Junger-Tas, Terlouw i Klein, 1994; Ručević, 2011).

Nadalje, također u skladu s postavljenom hipotezom, korelacije dobivene u ovome istraživanju upućuju na diferencijalnu povezanost dvaju aspekata neranjivosti (fizičke i psihološke) s povoljnim i nepovoljnim ishodima kod srednjoškolaca. Konkretnije, osjećaj fizičke neranjivosti umjereno je pozitivno povezan s količinom pušenja, dok nisu uočene povezanosti te varijable gotovo ni sjednim indikatorom zadovoljstva u različitim aspektima života. Iznimka je nizak negativni odnos fizičke neranjivosti i zadovoljstva zdravljem te sigurnošću u budućnost. S druge strane, osjećaj psihološke neranjivosti najslabije (vrlo nisko) je povezan s pušenjem, dok je sustavno pozitivno povezan sa zadovoljstvom srednjoškolaca u svim procijenjenim aspektima života. Ti nalazi idu u prilog gledištu na osjećaj psihološke neranjivosti kao na mogući psihološki resurs, koji tijekom razvoja u adolescentskoj dobi ima svojevrsnu funkciju osnaživanja osobe da se spremnije upusti u niz novih ponašanja, potencijalno važnih za ostvarivanje psihosocijalnih ciljeva svojstvenih adolescentskoj dobi (vezanih za odnose s roditeljima, vršnjacima itd.). Uspješno realiziranje osobno važnih ciljeva u određenoj domeni života odrazit će se i na ovaj aspekt subjektivne dobrobiti, tj. zadovoljstvo tim područjem života. Dobiveni drukčiji obrasci povezanosti fizičke i psihološke neranjivosti s nizom navedenih varijabli govore u prilog gledištu da se radi o dvama različitim konstruktima, koji bi mogli imati različite implikacije na funkcioniranje osobe.

Da fizička neranjivost nesumnjivo pridonosi objašnjenju učestalosti pušenja, vidi se i iz rezultata regresijske analize u kojoj je kao kriterij uvrštena čestina pušenja. Zanimljiv je podatak, koji se također može iščitati iz te tablice, da psihološka neranjivost ne doprinosi objašnjenju tog kriterija, odnosno nema značajan doprinos u predviđanju učestalosti toga rizičnog ponašanja. Ti rezultati idu u prilog tezi da su osjećaj fizičke i osjećaj psihološke neranjivosti dva različita konstrukta, od kojih je jedan (fizička neranjivost) prediktor rizičnoga zdravstvenog ponašanja (pušenja), dok drugi (psihološka neranjivost) nije nužno prediktor tih nepovoljnih ishoda.

Dobiveni nalazi o doprinosu tih dvaju aspekata neranjivosti procjenama općeg zadovoljstva životom srednjoškolaca pokazuju da osjećaj psihološke neranjivosti snažnije predviđa opće zadovoljstvo životom, i to u pozitivnom smjeru. Slični obrasci odnosa pronađeni su u istraživanju Lapsleya i Hilla (2010), gdje je čimbenik psihološke ranjivosti bio značajan pozitivan prediktor subjektivne dobrobiti, dok se čimbenik fizičke neranjivosti nije pokazao značajnim prediktorom subjektivne dobrobiti. Obrazac nalaza je konzistentan — psihološka neranjivost pozitivan je prediktor određenih indikatora uspješne prilagodbe (mjere dobrobiti), za razliku od osjećaja fizičke neranjivosti.

Usporedbom samoprocjena neranjivosti kod srednjoškolaca kvalitativno drukčijih iskustava s upuštanjem u rizična ponašanja (konzumacije cigareta), utvrđeno je da postoje razlike i u osjećaju fizičke neranjivosti među izdvojenim skupinama sudionika. U skladu s prijašnjim istraživanjima, adolescenti koji puše procijenili su se fizički neranjivijim od nepušača (Arnett, 2000; Halpern-Felsher, Biehl, Kropp i Rubinstein, 2004). U skladu s pretpostavkama, mogu se uočiti razlike u osjećaju fizičke neranjivosti među srednjoškolcima koji su izrazili drukčiju spremnost na upuštanje u ovaj oblik rizičnog ponašanja. Pri tome razlike u osjećaju fizičke neranjivosti među tim skupinama prate očekivani trend. Sudionici koji ne puše i nikada nisu ni probali pušiti, imaju najmanje procjene fizičke 
neranjivosti te se razlikuju od ostalih triju skupina. Najveća razlika u procjenama je od skupine pušača, malo manja od procjene bivših pušača i od onih koji su samo probali pušiti. Procjene onih koji su samo probali pušiti i onih koji nikada nisu ni probali, međusobno se razlikuju, odnosno sudionici koji su probali pušiti osjećaju se fizički neranjivije od učenika koji nisu ni probali. Nalazi Halpern-Felshera i sur. (2004) slični su utvrđenima u ovom istraživanju. Navedeni autori utvrdili su da adolescenti, koji su pušili i oni koji imaju namjeru pušiti, percipiraju rizike vezane za pušenje kao manje vjerojatne od onih koji nisu nikada pušili i koji nemaju ni namjeru. Stoga, možemo zaključiti kako je točna Frankenbergerova (2004) tvrdnja da adolescenti koji nisu nikako imali želju probati pušiti razvijaju različit stav i percepciju prema pušenju od onih koji su bili znatiželjni pa su probali.

Zanimljiva je skupina bivših pušača čije se procjene fizičke neranjivosti uspoređene s pušačima ne razlikuju, te se razlikuju od skupine sudionika koji nisu nikada pušili, a što je u skladu s ranijim nalazima Brighta, Mckillopa i Rydera (2008) da bivši pušači imaju izraženiji osjećaj neranjivosti od onih koji nisu nikada pušili.

$\mathrm{Na}$ osnovi navedenih nalaza možemo zaključiti da se osobe $s$ višom uključenosti u rizično ponašanje smatraju fizički neranjivije. Takvi podatci mogu se objasniti na različite načine. Teško je pretpostaviti da sudionici koji se upuštaju u rizično ponašanje, u ovom slučaju pušenje, nisu svjesni rizika koje ono nosi. Viscuvi (1990) navodi da ljudi ne samo da znaju koje rizike za zdravlje nosi pušenje već i precjenjuju vjerojatnost obolijevanja od istih, s time da su takve procjene još izraženije kod adolescenata. Halpern-Felsher (2011) navodi da su brojna istraživanja potvrdila taj Viscuvijev (1990) nalaz. Moguće objašnjenje takvih nalaza je u razlici između subjektivne i objektivne procjene vjerojatnosti oboljenja, odnosno u adolescentskom egocentrizmu (Elkind, 1967). Mladi, iako su svjesni objektivnog rizika pušenja, optimistični su i umanjuju rizik vlastitog oboljenja (Romer i Jamieson, 2001), odnosno pušači minimaliziraju rizik i imaju tendenciju vjerovati da se on više odnosi na druge, a manje na njih same (Weinstein, 1998). Romer i Jamieson (2001) navode da mladi pušači precjenjuju rizik od karcinoma pluća, ali podcjenjuju smrtnost od te bolesti. Osjećaj neranjivosti može se povezati i s nerealnim procjenama rizika kada je u pitanju stvaranje ovisnosti o pušenju. Roditis, Lee i Halpern-Felsher (2015) navode da mladi zapravo ne razumiju što znači ovisnost, odnosno često ne razumiju da ona označava poteškoće u prestajanju kada oni to budu željeli, kao i da će pušiti više nego to oni očekuju. Ti nalazi u skladu su s postavkama fizičke neranjivosti prema kojoj osoba, što je uvjerenija u vlastitu fizičku neranjivost, smatra da je otporna na stvaranje ovisnosti, odnosno da će moći prestati pušiti kada god bude smatrala da bi trebala ili željela. Isto tako, prema Halpern-Felsheru i sur. (2004) i Slovicu (1998) mladi, iako su načelno svjesni zdravstvenih i dugoročnih rizika povezanih s pušenjem, manje su svjesni da ono izaziva ovisnost. Pušači adolescenti manje su zabrinuti za dugoročne posljedice pušenja jer vjerojatno smatraju da lagano i jednostavno mogu prestati pušiti u bilo kojem trenutku (Arnett, 2000; Slovic, 1998).

Ukratko, dobiveni nalazi u skladu su s idejom da postoje različite dimenzije osjećaja neranjivosti te da imaju drukčije implikacije za pozitivne i negativne ishode kod adolescenata. 


\section{Ograničenja i smjernice za buduća istraživanja}

Kao i svako istraživanje i ovo ima nekoliko ograničenja. Prije svega, generalizaciju zaključaka izvedenih iz nalaza ovog istraživanja ograničava prigodan uzorak sudionika. $U$ budućim bi studijama istraživanje valjalo proširiti na reprezentativniji uzorak mladih adolescentske dobi. $U$ istraživanju su sudjelovali mladi s područja Slavonije, s time da je većina učenika (njih 75,4 \%) s područja Đakova, odnosno manjeg grada. Budući da je stopa pušača veća u urbanim sredinama i povećava se s urbanizacijom mjesta (Idris i sur., 2007) moguće je da bi odnos i broj pušača, bivših pušača i nepušača bio drugačiji u većim sredinama. Također, dob sudionika je, u ovom istraživanju, obuhvaćala srednju i stariju skupinu adolescenata, stoga bi radi adekvatnije provjere razvojnih trendova o pitanju konstrukta osjećaja neranjivosti, u budućim istraživanjima, trebalo uključiti i sudionike mlađe adolescentske dobi. Ako je funkcija razvoja psihološke neranjivosti olakšavanje razrješavanja razvojnih zadatka može se postaviti i pitanje što se s njom događa nakon adolescencije. Veća psihološka neranjivost trebala bi omogućiti i lakšu adaptaciju i ispunjavanje razvojnih zadataka pa tako Bjorklund i Green (1992) navode da osjećaj neranjivosti pomaže u preuzimanju rizika, olakšava psihološku separaciju od roditelja i olakšava adolescentima istraživanje novih ideja, uloga i zadataka. Međutim, s obzirom da svaki razvojni stadij ima svoje razvojne zadatke, postavlja se pitanje, što je s neranjivošću u ispunjavanju razvojnih zadataka drugih razvojnih perioda (na primjer, razvoju karijere, stvaranju vlastite obitelji i sl.), te je li percepcija fizičke neranjivosti povezana s nekim ozbiljnijim poteškoćama u ponašanju i u drugim dobnim skupinama.

Ograničenja vezana za fizičku neranjivost i pušenje ponajprije su vezana za broj sudionika istraživanja, posebice s obzirom da smo željeli usporediti skupine učenika koji su samo probali pušiti, one koji su pušili pa prestali i učenike koji još uvijek puše. Kada se uzorak raspodijeli na spomenute poduzorke, oni su relativno mali, stoga to ograničava snagu zaključaka u istraživanju. Također, nismo ispitali motive započinjanja, ali i prestanka pušenja (kod skupine sudionika koji su prestali pušiti), kao ni kada su počeli pušiti (odnosno prestali pušiti). Te bi spoznaje također pomogle u rasvjetljavanju problema ranog započinjanja pušenja i prevencije kao i odnosa fizičke neranjivosti s istim.

Jedno od ograničenja istraživanja vezano je i za korištenu Skalu osjećaja neranjivosti (Ćorić i sur., 2018). Taj je instrument odabran za operacionalizaciju aspekata neranjivosti u ovome istraživanju s obzirom na određena ograničenja ranije spomenute AIS skale. Primjerice čestice AIS skale formulirane su dosta općenito (npr. „Pravila sigurnosti se ne odnose na mene“, „Ranjiva sam osoba” ili „Mjere opreza su više bitne drugima nego meni”) što ostavlja više prostora za razlike u interpretaciji pitanja kod različitih sudionika. Skala osjećaja neranjivosti (Ćorić i sur., 2018) konstruirana je s namjerom da se mjerenje konstrukta unaprijedi s obzirom na navedena ograničenja. Odabrana je kao primjerena jer također sadrži dvije supskale, fizičke i psihološke neranjivosti. Česticama su obuhvaćena ponašanja kojima se ispunjavaju relevantni zadatci tog perioda, odnosno moguća rizična ponašanja vezana za njih. Od tih ponašanja najznačajnija su: postajanje emocionalne nezavisnosti od roditelja i drugih odraslih, formiranje vlastitog identiteta, vrijednosti i uvjerenja, ostvarivanje intimne povezanosti i intimnog odnosa. U navedenu skalu uključena su i ponašanja aktualna današnjim adolescentima poput upoznavanja partnera putem interneta i sl. Autori instrumenta izvještavaju da Skala osjećaja neranjivosti objašnjava 13,20 \% dodatne varijance rizičnog ponašanja u odnosu na njoj kongruentnu AIS skalu (prema Ćorić i sur., 2019). Ipak, s obzirom da 
se radi o novijem instrumentu, poželjne su daljnje provjere njezinih psihometrijskih karakteristika jer su one još uvijek nedovoljno istražene.

Isto tako, u budućim istraživanjima bilo bi korisno istražiti postoji li medijacijski odnos percepcije rizika i percepcije koristi pušenja u odnosu osobne neranjivosti i pušenja jer se pokazuje da adolescenti koji puše percipiraju manje rizike i više koristi povezanih s pušenjem od nepušača (Morrell, Lapsley i Halpern-Felsher, 2016). Nadalje, kad je riječ o konstruktu neranjivosti, zdravstvene kampanje koje bi ciljale na povećanje ranjivosti kod adolescenata su poželjne, no postoji potreba za preciznim zahvaćanjem fizičkog aspekta neranjivosti koji se pokazao kao prediktor pušenja i negativan prediktor subjektivne dobrobiti. Međutim, psihološku neranjivost trebalo bi mobilizirati i koristiti se kao psihosocijalnim resursom jer se pokazala u ovom istraživanju kao prediktor subjektivne dobrobiti, ali isto tako neka prethodna istraživanja pokazuju da je negativno povezana s depresivnim i interpersonalnim problemima te problemima sa samopoštovanjem (Aalsma, Lapsley i Flannery, 2006; Lapsley i Hill, 2010). Dakle, neranjivost nije unidimenzionalan konstrukt, niti ima unidimenzionalne posljedice i implikacije za promicanje zdravlja.

Rizično ponašanje operacionalizirano je pušenjem cigareta koje je po mnogočemu slično i nekim drugim oblicima rizičnog ponašanja, poput konzumacije alkohola: postoji pozitivno kratkoročno potkrepljenje, ima simboliku odraslosti (mladi se osjećaju odraslo dok puše), roditelji ga zabranjuju te je nezakonita supstancija maloljetnicima (Goldberg, Halpern-Felsher i Millstein, 2002). Međutim, bilo bi dobro ispitati je li utvrđeni odnos fizičke neranjivosti i rizičnog ponašanja istovjetan i kod drugih rizičnih ponašanja.

Kao i kod većine istraživanja rizičnog ponašanja i njihovih prediktora, postavlja se pitanje mogućnosti prevencije, odnosno kako utvrđene podatke implementirati u postojeće preventivne programe, odnosno kako ih osuvremeniti i poboljšati. Da je pušenje (kao i ostala rizična ponašanja) štetno, zna većina mladih koji započinju pušiti. Međutim, i dalje postoji veliki problem ranog započinjanja pušenja kao i mladih koji postaju ovisnici o pušenju. Spoznaje o fizičkoj neranjivosti kod mladih pušača rasvjetljuju tu naizgled kontradiktornu spoznaju. Ovim istraživanjem također je utvrđeno da mladi koji se rizičnije ponašaju (puše) imaju jači osjećaj fizičke neranjivosti, stoga je moguće da kampanje koje ciljaju upozoriti mlade na negativne posljedice pušenja tako što će ih uplašiti brojnim negativnim posljedicama, možda neće polučiti željenim rezultatima. To potvrđuju i neka ranija istraživanja, kao na primjer istraživanje Siegela i Bienera (2000). U navedenom se istraživanju medijsko oglašavanje protiv pušenja pokazalo učinkovitim samo kod mlađih adolescenata (12 i 13 godina) dok na starije adolescente (14 i 15 godina) nije imalo utjecaja. Uzimajući u obzir razvojne zadatke koje mladi razrješavaju u tom razdoblju, ovakvi nalazi nisu neobični. Dok je u ranoj adolescenciji važan fizički razvoj i pubertet (Byler i sur., 1969, prema Millstein i HalpernFelsher, 2002), u srednjoj je adolescenciji važan izgled, odnosi s prijateljima kao i sviđanje osobama suprotnog spola (Millstein i Halpern-Felsher, 2002). Stoga, kampanje bi trebale ciljati na "mlađe" adolescente kod kojih se pokazalo da kampanje protiv pušenja imaju utjecaj. S tim više što su ranija istraživanja utvrdila da rana pozitivna iskustva s rizičnim ponašanjem povećavaju vjerojatnost upuštanja i u druga rizična ponašanja (Goldberg, Halpern-Felsher i Millstein, 2002) tako da bi s kampanjama trebalo krenuti što ranije. Isto tako, prilikom edukacija, posebice kod mlađih adolescenata, važno je objasniti posljedice pušenja na njima razumljiv način, da bi, npr. uistinu razumjeli što znači ovisnost i što ona sa sobom nosi. 
Marija Milić, Ružica-Marija Vlajčić, Valerija Križanić: Percepcija neranjivosti, upuštanje u rizična...

S obzirom da naglašavanje negativnih posljedica nema učinak koji bi stručnjaci i autori preventivnih programa očekivali, postavlja se pitanje što onda učiniti. Preventivni bi programi trebali stavljati naglasak na zdravu okolinu (umjesto naglašavanja štetnosti pušenja) kao i prednosti nepušenja s obzirom da adolescenti koji puše s vremenom smanjuju značaj rizika, a naglasak stavljaju na prednosti pušenja (Morell, Song, Halpern-Felsher, 2010). Isto tako, valjalo bi naglasak stavljati na one čimbenike koji su njima u tom životnom razdoblju važni, kao na primjer odnose s prijateljima. Tome u prilog ide i nalaz istraživanja (Morell, Song, Halpern-Felsher, 2010) koji je utvrdio da adolescenti koji imaju više od šest prijatelja koji puše češće naglašavaju prednosti pušenja od onih čiji prijatelji nisu pušači pa se samim tim može očekivati da će i oni sami prije početi pušiti od mladih čiji prijatelji ne puše. Također, važan nalaz ranijih istraživanja je i da adolescenti, koji u većoj mjeri percipiraju prednosti pušenja, imaju i veću vjerojatnost započinjanja s tom navikom u odnosu na one koji to ne vide (Song i sur., 2009). Percipirane socijalne prednosti (kao što su dojam da osobe izgledaju "cool", osjećaj opuštenosti, popularnost, osjećaj odraslosti) povećavaju vjerojatnost pušenja (Aryal, Petzold i Krettek, 2013). Stoga se kampanje protiv pušenja trebaju više usmjeriti na taj dio, odnosno utjecati na percepciju mladih o (percipiranim prednostima) pušenja u većoj mjeri nego na naglašavanje negativnosti s obzirom da se one s osjećajem fizičke neranjivosti umanjuju. Neki autori (npr. Goldberg i sur., 2002) čak navode da će adolescenti ulaziti u rizična ponašanja iako su svjesni rizika jer je rizik manje važan od percepcije dobitka koji imaju od tog ponašanja. Moguće da upravo zbog osjećaja neranjivosti zanemaruju rizik, a naglašavaju samo percepciju prednosti u procjeni. Stoga bi buduća istraživanja trebala ispitati percepcije rizika i percepciju koristi pušenja u odnosu na procjene fizičke neranjivosti.

Halpern-Felsher (2011) navodi da je tek u manjem broju istraživanja uspoređena sklonost rizičnom ponašanju odraslih i adolescenata. Bilo bi dobro u budućim istraživanjima ispitati kakav je odnos osjećaja fizičke neranjivosti i rizičnog ponašanja kao i kasniji tijek fizičke neranjivosti. Mahalik, Coley, Lombardi, Lynch, Markowitz i Jaffee, (2013) navode da pojavnost ponašanja rizičnih za zdravlje postupno raste do ranih 20-ih godina te se tada ustaljuje ili opada. Bez obzira na sve kampanje i sve veći broj dokaza o štetnosti pušenja 2015. godine u Hrvatskoj je pušilo 31,1 \% ljudi starijih od 15 godina (prema Hrvatskom zavodu za javno zdravstvo [HZJZ], 2015). Pitanje je, koliko se osjećaj fizičke neranjivosti u odrasloj dobi razlikuje kod osoba koje puše i onih koji ne puše. Ostaje otvoreno pitanje što je s fizičkom neranjivošću u odrasloj dobi te koliko se ona razlikuje kod osoba koje se upuštaju u rizična ponašanja (poput pušenja) i onih koji to ne čine.

\section{Zaključak}

Nalazi provedenog istraživanja govore u prilog pretpostavkama da su percepcija fizičke i psihološke neranjivosti povezani, ali ipak različiti konstrukti. Osjećaj fizičke neranjivosti značajno se razlikuje među srednjoškolcima s različitim iskustvima upuštanja u rizična ponašanja (pušenja) — taj je osjećaj najmanji kod srednjoškolaca koji nikada nisu pušili, a najveći kod srednjoškolaca koji puše. Istraživanjem je također utvrđeno da fizička neranjivost pridonosi objašnjenju učestalosti pušenja, dok se osjećaj psihološke neranjivosti nije pokazao kao statistički značajan prediktor učestalosti toga rizična ponašanja. Za razliku od fizičke, psihološka neranjivost pozitivno je povezana sa zadovoljstvom u svim ispitanim aspektima života te doprinosi objašnjenju varijance općeg zadovoljstva 
životom. Ukratko, dobiveni nalazi idu u prilog tezi da postoje različite dimenzije osjećaja neranjivosti koje imaju drukčije implikacije za pozitivne i negativne ishode kod adolescenata.

\section{Literatura}

Aalsma, M., Lapsley, D.K., Flannery, D. (2006). Personal fables, narcissism, and adolescent adjustment. Psychology in the Schools. 43 (4), 481-491. doi: 10.1002/pits.20162

Alberts, A., Elkind, D., Ginsberg, S. (2007). The personal fable and risk-taking in early adolescence. Journal of Youth and Adolescence, 36, 71-76. doi: 10.1007/s10964-006-9144-4

Antaramian, S.P., Huebner, E.S., Valois, R.F. (2008). Adolescent life satisfaction. Applied Psychology: An International Review, 57(1), 112-126. doi: 10.1111/j.1464-0597.2008.00357.x

Arnett, J. (1992). Reckless behavior in adolescence: A developmental perspective. Developmental review, 12(4), 339-373. doi: 10.1016/0273-2297(92)90013-R

Arnett, J.J. (2000). Optimistic bias in adolescent and adult smokers and nonsmokers. Addictive Behaviors, 25(4), 625-632. doi: 10.1016/S0306-4603(99)00072-6

Aryal, U.R., Petzold, M., Krettek, A. (2013). Perceived risks and benefits of cigarette smoking among Nepalese adolescents: a population-based cross-sectional study. BMC public health, 13, 187. Preuzeto s: http://www.biomedcentral.com/1471-2458/13/187 (25. 10. 2019).

Bennett, S., Farrington, D.P., Huesmann, L.R. (2005). Explaining gender differences in crime and violence: The importance of social cognitive skills. Aggression and Violent Behavior, 10(3), 263-288. doi: 10.1016/j.avb.2004.07.001

Bjorklund, D.F., Green, B.L. (1992). The adaptive nature of cognitive immaturity. American Psychologist, 47(1), 46-54. doi: 10.1037/0003-066X.47.1.46

Bonilha, A.G., de Souza, E.S.T., Sicchieri, M.P., Achcar, J.A., Crippa, J.A.S., Baddini-Martinez, J. (2013). A motivational profile for smoking among adolescents. Journal of Addiction Medicine, 7(6), 439-446. doi: 10.1097/01.ADM.0000434987.76599.c0

Bright, S.J., Mckillop, D., Ryder, D. (2008). Cigarette smoking among young adults: Integrating adolescent cognitive egocentrism with the trans-theoretical model. Australian Journal of Psychology, 60(1), 18-25. doi: 10.1080/00049530701458043

Cohen, J. (1988). Statistical power analysis for the behavior sciences. Hillsdale, NJ: Erlbaum.

Cohn, L.D., Macfarlane, S., Yanez, C., Imai, W.K. (1995). Risk-perception: Differences between adolescents and adults. Health Psychology, 14(3), 217-222. doi: 10.1037/0278-6133.14.3.217

Ćorić, M., Vlajčić, R.M., Kolak, M., Goretić, I. (2018). Konstrukcija skale Osjećaja neranjivosti. Neobjavljene bilješke s kolegija Konstrukcija i interpretacija testova. Osijek: Filozofski fakultet.

Dečković Vukres, V., Uhernik, A.I, Mihel, S. (2015). Istraživanje o uporabi duhana u odrasloj populaciji Republike Hrvatske. Zagreb: Hrvatski zavod za javno zdravstvo (HZJZ). Preuzeto s: https://www.hzjz.hr/wp-content/uploads/2016/02/Duhan_2015.pdf (25. 10. 2019)

Diener, E., Suh, E.M., Lucas, R.E., Smith, H.L. (1999). Subjective well-being: Three decades of progress. Psychological Bulletin, 125(2), 276-302. doi: 10.1037/0033-2909.125.2.276

Elkind, D. (1967). Egocentrism in Adolescence. Child Development, 38(4), 1025-1034. doi: $10.2307 / 1127100$ 
Marija Milić, Ružica-Marija Vlajčić, Valerija Križanić: Percepcija neranjivosti, upuštanje u rizična...

Ellickson, P.L., Tucker, J.S., Klein, D.J. (2001). High-risk behaviors associated with early smoking: results from a 5-year follow-up. The Journal of adolescent health, 28, 465-473. doi: 10.1016/S1054-139X(00)00202-0

Fidler, J.A., Wardle, J., Henning Brodersen, N., Jarvis, J.M., West, R. (2006). Vulnerability to smoking after trying a single cigarette can lie dormant for three years or more, Tobacco Control, 15(3), 205-206. doi: 10.1136/tc.2005.014894

Field, A. (2013). Discovering Statistics Using IBM SPSS, 4th Edition. London: Sage Publications.

Frankenberger, K.D. (2004). Adolescent Egocentrism, Risk Perceptions, and Sensation Seeking Among Smoking and Nonsmoking Youth. Journal of Adolescent Research, 19(5), 576-590. doi: $10.1177 / 0743558403260004$

Gerrard, M., Gibbons, F.X., Benthin, A.C., Hessling, R.M. (1996). A longitudinal study of the reciprocal nature of risk behaviors and cognitions in adolescents: what you do shapes what you think, and vice versa. Health Psychology, 15(5), 344-354. doi: 10.1037/02786133.15.5.344

Gilman, S.E., Rende, R., Boergers, J., Abrams, D.B., Buka, S.L., Clark, M.A. i dr. (2009). Parental smoking and adolescent smoking initiation: An intergenerational perspective on tobacco control. Pediatrics, 123(2), 274-281. doi: 10.1542/peds.2008-2251

Goldbeck, L., Schmitz, T., Besier, T., Herschbach, P., Henrich, G. (2007). Life satisfaction decreases during adolescence. Quality of Life Research, 16(6), 969-979. doi: 10.1007/s11136007-9205-5

Goldberg, J.H., Halpern-Felsher, B.L., Millstein, S.G. (2002). Beyond Invulnerability: The Importance of Benefits in Adolescents' Decision to Drink Alcohol. Health psychology, 21(5), 477484. doi: 10.1037/0278-6133.21.5.477

Good, G.E., Sherrod, N.B., Dillon, M.G. (2000). Masculine gender role stressor and men's health. U: R.M. Eisler i M. Hersen (ur.): Handbook of gender, culture and health (str. 63-81). New Jersey: Lawrence Erlbaum Associates.

Halpern-Felsher, B.L. (2011). Adolescent Decision-Making. U: B.B. Brown i M. Prinstein (ur.), Encyclopedia of Adolescence, 1rt Vol. (str. 30-37). San Diego: Academic Press.

Halpern-Felsher, B.L., Biehl, M., Kropp, R., Rubinstein, M. (2004). Perceived risks and benefits of smoking: Differences among adolescents with different smoking experiences and intentions. Preventive Medicine, 39(3), 559-567. doi: 10.1016/j.ypmed.2004.02.017

Haranin, E., Huebner, E.S., Suldo, S.M. (2007). Predictive and incremental validity of global and domain-based adolescent life satisfaction reports. Journal of Psychoeducational Assessment, 25(2), 127-138. doi: 10.1177/0734282906295620

Hawkins, W.E., Hawkins, M.J., Seeley, J. (1992). Stress, health-related behavior and quality of life on depressive symptomatology in a sample of adolescents. Psychological Reports, 71(1), 183-186. doi: 10.2466/pr0.1992.71.1.183

Hill, P.L., Duggan, P.M., Lapsley, D. (2012). Subjective Invulnerability, Risk Behavior, and Adjustment in Early Adolescence. The Journal of Early Adolescence, 32(4), 489-501. doi: 10.1177/0272431611400304

Huebner E. (2004). Research on assessment of life satisfaction of children and adolescents. Social Indicators Research, 66(1/2), 3-33. doi: 10.1023/B:SOCl.0000007497.57754.e3 
Idris, B.I., Giskes, K., Borrell, C., Benach, J., Costa, G., Federico, B., Helakorpi, S. i sur. (2007). Higher smoking prevalence in urban compared to non-urban areas: time trends in six European countries. Health \& Place, 13(3), 702-712. doi: 10.1016/j.healthplace.2006.11.001.

Junger-Tas, J., Terlouw, G.J., Klein, M.W. (1994). Delinquent behavior among young people in the western world. Amsterdam, NL: Kugler Publications.

Kalebić Maglica, B., Martinac Dorčić, T. (2015). Osobine ličnosti i socijalni faktori kao odrednice konzumacije cigareta i alkohola kod adolescenata. Društvena istraživanja, 24(2), 197217. doi: $10.5559 /$ di.24.2.02

Kaliterna Lipovčan, Lj., Prizmić Larsen, Z., Brkljačić, Z. (2011). Međunarodni indeks dobrobiti - podaci za Hrvatsku. U: G. Vuletić (ur.): Kvaliteta života i zdravlja (41-51). Osijek: Filozofski fakultet Sveučilišta u Osijeku.

Khosravi, A., Mohammadpoorasl, A., Naieni, K., Mahmoodi, M., Pouyan, A.A., Mansournia, M.A. (2016). Causal Effect of Self-esteem on Cigarette Smoking Stages in Adolescents: Coarsened Exact Matching in a Longitudinal Study. Osong Public Health and Research Perspectives, 7(6), 341-345. doi: 10.1016/j.phrp.2016.10.003

Koivumaa-Honkanen, H., Honkanen, R., Koskenvuo, M., Viinamäki, H., Kaprio, J. (2002). Life dissatisfaction as a predictor of fatal injury in a 20-year follow-up. Acta Psychiatrica Scandinavia, 105(6), 444-450. doi: 10.1034/j.1600-0447.2002.01287.x

Koivumaa-Honkanen, H., Honkanen, R., Viinamäki, H., Heikkilä, K., Kaprio, J., Koskenvuo, M. (2001). Life satisfaction and suicide: A 20-year follow-up study. The American Journal of Psychiatry, 158(3), 433-439. doi: 10.1176/appi.ajp.158.3.433

Kovčo Vukadin, I., Novak, M., Križan, H. (2016). Zadovoljstvo životom: individualna i obiteljska perspektiva. Kriminologija i socijalna integracija, 24(1), 84-115. doi: 10.31299/ksi.24.1.4

Kriesi, I., Buchmann, M. (2012). Educational success and adolescents' well-being in Switzerland. Swiss Journal of Sociology, 38(2), 245-265. doi: 10.5167/uzh-68739

Krosnick, J.A., Chang, L., Sherman, S.J., Chassin, L., Presson, C. (2006). The effects of beliefs about the health consequences of cigarette smoking on smoking onset. Journal of Communication, 56(1), 18-37. doi: 10.1111/j.1460-2466.2006.00281.x

Lapsley, D. (2003). The two faces of adolescent invulnerability. U D. Romer (ur.), Reducing adolescent risk: Toward an integrated approach (str. 25-31). Newbury Park, CA: Sage. doi: 10.4135/9781452233611.n4

Lapsley, D.K., FitzGerald, D., Rice, K., Jackson, S. (1989). Separation-individuation and the "new look" at adolescent egocentrism: A test of an integrative model. Journal of Adolescent Research, 32(4), 483-505. doi: 10.1177/0272431611400304

Lapsley, D.K., Hill, P.L. (2010). Subjective Invulnerability, Optimism Bias and Adjustment in Emerging Adulthood. Journal of Youth Adolescence, 39, 847-857. doi: 10.1007/s10964-009-9409-9

Mahalik, J.R., Coley, R.L., Lombardi, C.M., Lynch, A.D., Markowitz, A.J., Jaffee, S.R. (2013). Changes in health risk behaviors for males and females from early adolescence through early adulthood. Health Psychology, 32(6), 685-694. doi: 10.1037/a0031658

Martin, K.M., Huebner, E.S., Valois, R.F. (2008). Does life satisfaction predict adolescent victimization? Psychology in the Schools, 45(8), 419-431. doi: 10.1002/pits.20336

Millstein, S.G., Halpern-Felsher, B. (2002). Perceptions of Risk and Vulnerability. Journal of Adolescent Health, 31(1), 10-27. doi: 10.1016/S1054-139X(02)00412-3 
Marija Milić, Ružica-Marija Vlajčić, Valerija Križanić: Percepcija neranjivosti, upuštanje u rizična...

Morrell, H.E., Lapsley, D.K., Halpern-Felsher, B.L. (2016). Subjective invulnerability and perceptions of tobacco-related benefits predict adolescent smoking behavior. Journal of Early Adolescence, 36(5), 679-703. doi: 10.1177/0272431615578274

Morrell, H.E., Song, A.V., Halpern-Felsher, B.L. (2010). Predicting adolescent perceptions of the risks and benefits of cigarette smoking: A longitudinal investigation. Health Psychology, 26(6), 610-617. doi: 10.1037/a0021237

Newcomb, M.D., Bentler, P.M., Collins, C. (1986). Alcohol use and dissatisfaction with self and life: A longitudinal analysis of young adults. Journal of Drug Issues, 16(4), 479-494. doi: 10.1177/002204268601600401

Nolen-Hoeksema, S., Rusting, C.L. (1999). Gender differences in well-being. U: D. Kahnema, E. Diener i N. Schwartz (ur.): Well-being: The foundations of hedonic psychology (str. 330-352). New York: Russell Sage Foundation.

O'Loughlin, J.O., Karp, I., Koulis, T., Paradis, G., DiFranza, J. (2009). Determinants of first puff and daily cigarette smoking in adolescents. American Journal of Epidemiology, 170(5), 585-597. doi: 10.1093/aje/kwp179

Ottová-Jordan V., Smith O.R., Gobina I., Mazur J., Augustine L., Cavallo F. i dr. (2015). Trends in multiple recurrent health complaints in 15-year-olds in 35 countries in Europe, North America and Israel from 1994 to 2010. European Journal of Public Health, 25(2), 24-27. doi: 10.1093/eurpub/ckv015

Park, H.S., Koo, H.Y., Schepp, K.G. (2005). Predictors of suicidal ideation for adolescents by gender. Taehan Kanho Hakhoe Chi, 35(8), 1433-1442. doi: 10.4040/jkan.2005.35.8.1433

Pejnović Franelić, I., Markelić, M., Muslić, Lj., Musić Milanović, S., Pavić Šimetin, I., Mayer, D. i dr. (2016). Europsko istraživanje o pušenju, pijenju i uzimanju droga među učenicima ES$P A D$, Zagreb: Hrvatski zavod za javno zdravstvo (HZJZ). Preuzeto s: https://www.hzjz. hr/wp-content/uploads/2016/10/HR_ESPAD_2015_RGB_3.pdf (25. 10. 2019).

Räikkönen, E., Kokko, K., Chen, M., Pulkkinen, L. (2012). Patterns of adult roles, their antecedents and psychosocial wellbeing correlates among Finns born in 1959. Longitudinal and Life Course Studies, 3 (2), 211-227. doi: 10.14301/llcs.v3i2.180

Roditis, M., Lee, J., Halpern-Felsher, B.L. (2016). Adolescent (Mis)Perceptions About Nicotine Addiction: Results From a Mixed-Methods Study. Health education \& behavior, 43(2), 156-164. doi: 10.1177/1090198115598985

Rodriguez, D., Romer, D., Audrain-McGovern, J. (2007). Beliefs about the risks of smoking mediate the relationship between exposure to smoking and smoking. Psychosomatic Medicine, 69(1), 106-113. doi: 10.1111/j.1460-2466.2006.00281.x

Romer, D., Jamieson, P. (2001). Do adolescents appreciate the risks of smoking? Evidence from a national survey. Journal of Adolescent Health, 29(1), 12-21. doi: 10.1016/S1054139X(01)00209-9

Roothman, B., Kirsten, D., Wissing, M. (2003). Gender differences in aspects of psychological well-being. South African Journal of Psychology, 33(4), 212-218. doi: 10.1177/008124630303300403

Ručević, S. (2011). Povezanost privrženosti roditeljima s rizičnim i delinkventnim ponašanjem kod adolescenata. Društvena istraživanja, 20(1), 167-187. doi: 10.5559/di.20.1.09

Salmela-Aro, K., Ek, E., Taanila, A., Chen, M. (2012). Role configurations in young adulthood, antecedents, and later well-being among Finns born in 1966. Longitudinal and Life Course Studies, 3(2), 228-242. doi: 10.14301/Ilcs.v3i2.184 
Sarason, I.G., Mankowski, E.S., Peterson, A.V., Dinh, K.T. (1992). Adolescents' reasons for smoking. Journal of School Health, 62(5), 185-190. doi: 10.1111/j.1746-1561.1992.tb06039.x

Schoon, I., Martin, P., Ross, A. (2007). Career transitions in times of social change. His and her story. Journal of Vocational Behavior, 70(1), 78-96. doi: https://doi.org/10.1016/j.jvb.2006.04.009

Schulenberg, J.E., Bryant, A.L., O'Malley, P.M. (2004). Taking hold of some kind of life: How developmental tasks relate to trajectories of well-being during the transition to adulthood. Development and Psychopathology, 16(4), 1119-1140. doi:10.1017/S0954579404040167

Siegel, M., Biener, L. (2000). The Impact of an Anti smoking Media Campaign on Progression to Established Smoking: Results of a Longitudinal Youth Study. American Journal of Public Health, 90(3), 380-386. doi: 10.2105/ajph.90.3.380

Slovic, P. (1998). Do adolescent smokers know the risks? Duke Law Journal, 47(6), 1133-1141. doi: $10.2307 / 1373033$

Song, A.V., Morrell, H.E.R., Cornell, J.L., Ramos, M.E., Biehl, M., Kropp, R.Y., Halpern-Felsher, B. L. (2009). Perceptions of smoking-related risks and benefits as predictors of adolescent smoking initiation. American Journal of Public Health, 99(3), 487-492. doi: 10.2105/ AJPH.2008.137679

Steinberg, I. (2008). A Social Neuroscience Perspective on Adolescent Risk-Taking. Developmental review, 28(1), 78-106. doi: 10.1016/j.dr.2007.08.002

Suldo, S.M., Huebner, E.S. (2004). Does life satisfaction moderate the effects of stressful life events on psychopathological behavior during adolescence? School Psychology Quarterly, 19(2), 93-105. doi: 10.1521/scpq.19.2.93.33313

Šikić-Mićanović, L. (1997). Socialization and gender: the significance of socio cultural contexts. Društvena istraživanja, 6(4-5), 577-595.

Taylor, S.E., Gollwitzer, P.M. (1995). Effect of mindset on positive illusions. Journal of Personality and Social Psychology, 69(2), 213-226. doi: 10.1037//0022-3514.69.2.213

Trimpop, R.M. (1994). What Are the Consequences of Risk Taking Behavior? U: Trimpop, R. M. (ur.): The Psychology of Risk Taking Behavior Advances in Psychology (181-210). Amsterdam, NL: Elsevier doi: 10.1016/s0166-4115(08)61301-1

U.S. Department of Health and Human Services (USDHHS), Centers for Disease Control and Prevention, National Center for Chronic Disease Prevention and Health Promotion, Office on Smoking and Health. (2014). The health consequences of smoking-50 years of progress. A report of the surgeon general. Preuzeto s: https://www.ncbi.nlm.nih.gov/ pubmed/24455788 (20.11.2019.).

Veenhoven, R. (2000). The Four Qualities of Life Ordering Concepts and Measures of the Good Life. Journal of Happiness Studies, 1(1), 1-39. doi: 10.1007/978-94-007-5702-8_11

Viscusi, W.K. (1990). Do smokers underestimate risks? Journal of Political Economy, 98(6), 12531269. doi: $10.1086 / 261733$

Weinstein, N.D. (1998). Accuracy of smokers' risk perceptions. Annals of Behavioral Medicine, 20(2), 135- 140. doi: 10.1080/14622299050011721

Weinstein, N.D., Klein, W.M. (1996). Unrealistic optimism: present and future. Journal of Social and Clinical Psychology, 15(1), 1-8. doi: 10.1521/jscp.1996.15.1.1

World Health Organization (WHO). Regional Office for Europe. (2016). Growing up unequal: gender and socioeconomic differences in young people's health and well-being. World Health 
Marija Milić, Ružica-Marija Vlajčić, Valerija Križanić: Percepcija neranjivosti, upuštanje u rizična...

Organization. Regional Office for Europe. Preuzeto s: https://apps.who.int/iris/handle/10665/326320 (20.11. 2019).

Zloković, J., Vrcelj, S. (2010). Rizična ponašanja djece i mladih. Odgojne znanosti, 12(1), 197-213.

Zullig, K.J., Valois, R.F., Huebner, E.S., Oeltmann, J.E., Drane, J.W. (2001). Relationship between perceived life satisfaction and adolescents' substance abuse. Journal of Adolescent Health, 29(4), 279-288. doi: 10.1016/S1054-139X(01)00269-5 
Marija Milić

Department of Psychology, Faculty of Humanities and Social Sciences, Josip Juraj Strossmayer University of Osijek

Ružica-Marija Vlajčić

Valerija Križanić

Department of Psychology, Faculty of Humanities and Social Sciences, Josip Juraj Strossmayer University of Osijek

\title{
Perception of invulnerability, engaging in risky behaviors and life satisfaction among high school students
}

\begin{abstract}
A sense of invulnerability is commonly associated only with adolescents' risk behaviors, but according to some developmental theories, it is also an adaptive response to developmental tasks that occur during that period of life. The objective of this paper was to explore two aspects of the sense of invulnerability (physical and psychological) on a sample of high school students. More specifically, the relationship between physical and psychological invulnerability in terms of engagement in risky behaviors (cigarette use) on the one hand and indicators of subjective wellbeing (life satisfaction) on the other was explored. The data from 297 adolescents aged 16 to 20 years ( $M=17.33 ; S D=0.834 ; 54.2 \%$ girls) were analyzed. The study found that boys' assessment of physical and psychological invulnerability was higher in comparison to girls' assessment. Smokers rated their physical invulnerability higher than adolescents who had quit smoking, who had only tried smoking and those who had never smoked. While physical invulnerability was not associated with life assessments in most domains of life satisfaction, psychological was positively associated with all domains as well as general life satisfaction. The findings also showed that assessing psychological invulnerability contributed more to explaining life satisfaction than assessing physical invulnerability, whereas physical invulnerability was a significant predictor of smoking frequency among adolescents. The results of this study indicate the significance and importance of both domains of invulnerability in adolescence.
\end{abstract}

Key words: adolescents, physical and psychological invulnerability, smoking, life satisfaction 